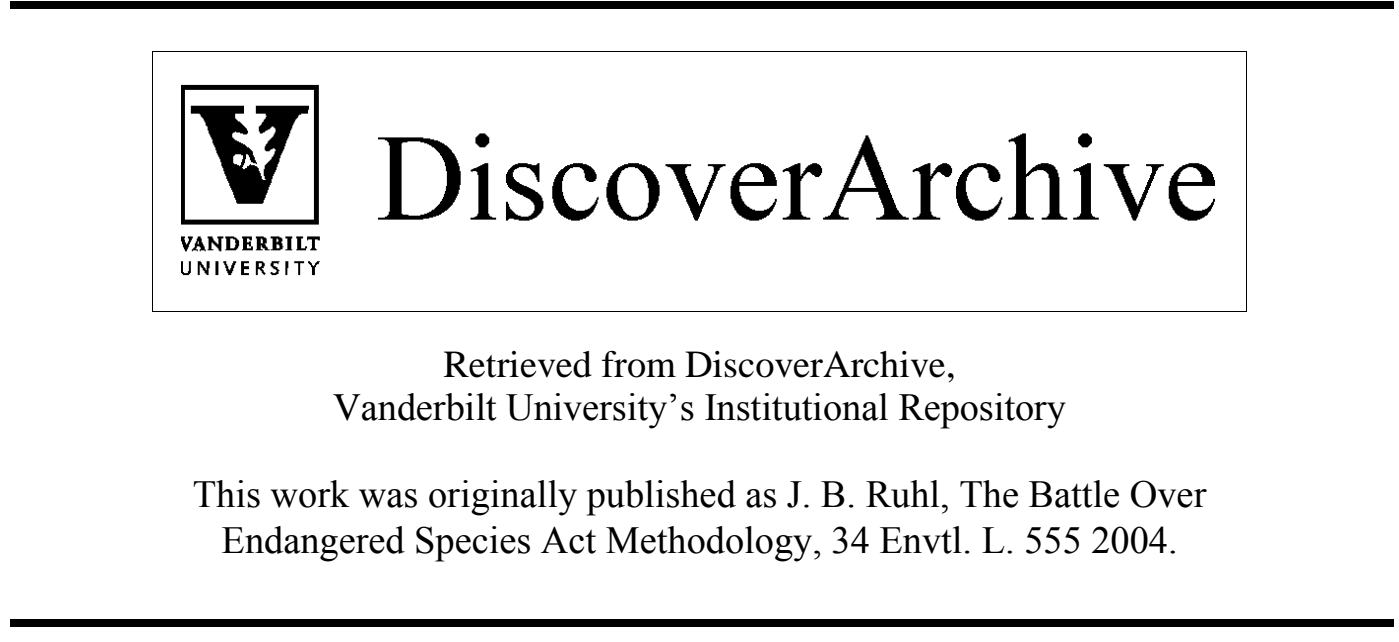




\title{
THE BATTLE OVER ENDANGERED SPECIES ACT METHODOLOGY
}

\author{
BY
}

J.B. RUHL

The substantive contours of the Endangered Species Act (ESA) have been largely worked out for quite some time. Starting in the mid1990s, however, opponents of Fish and Wildlife Service (FWS) and National Marine Fisheries Service (NMFS) decisions realized that the methodological contours of the ESA were not nearly as settled as their substantive kin. Industry and environmental interests alike appreciate that how these methodological rules get worked out could revolutionize the ESA for decades to come, and during the late 1990s they opened the debate over ESA methodology and have been going strong at it ever since.

This Article explores the breadth and depth of the ensuing battle over ESA methodology. It begins by laying out a framework for evaluating decision-making methodologies. One basis on which we might choose how to go about making decisions is the level of confidence we wish decisions to enjoy. Also, how we frame the hypotheses to be tested will influence who favors which methodology. And methodology selection also has much to do with aversion to mistaken conclusions about whether the hypothesis is true.

The Article then provides some background on the ESA and its numerous decision-making nodes - the points at which a choice among the three methodologies must be made using one or more of the frameworks discussed above. ESA decision making is particularly susceptible to fights over methodology. First, many ESA decisions involve questions of biological science for which the available scientific database is either sparse or inconclusive. Second, ESA decision contexts often present a poor fit between science and policy. Finally, ESA decisions are characterized by the intense involvement of viciously combative interest groups willing to sue each other and the agencies over almost any issue, and particularly over methodology.

\footnotetext{
(C) J.B. Ruhl, 2004. Matthews \& Hawkins Professor of Property, Florida State University College of Law, Tallahassee, Florida. I am thankful to Dan Tarlock, Holly Doremus, and Deborah Brosnan for comments on drafts of this Article, to participants in workshops and symposia at Florida State and Lewis and Clark law schools for their helpful observations, to the staff at Environmental Law for their useful input, and to Bridget Kellogg for research assistance. Please direct all comments or questions about this Article to jruhl@law.fsu.edu.
} 
Next the Article frames and assesses the battle positions, which fall into three competing methodological camps-the Professional Judgment Method, which is the default rule for the ESA, and its two postulated alternatives, the Scientific Method and the Precautionary Principle Method. These three methodologies incorporate starkly different approaches to management of risk relating to species conservation. Yet, close examination reveals neither of the postulated alternatives to the Professional Judgment Method finds support in the statutory framework of the ESA.

Nevertheless, there are times when the Scientific Method and the Precautionary Principle Method should have a role to play under the ESA, sometimes even hand-in-hand. The challenge is to design a framework that both gives them a role and keeps them under control. The final section of the Article outlines a proposal to create a procedure under which FWS and NMFS could elect to adopt the Precautionary Principle Method in discrete decision-making instances, but in such instances the agency must obtain a rigorous scientific peer review of the basis for the agency's decision as a means of checking against irrational or unjustified precaution. Conversely, the proposal would also establish a process under which, in limited circumstances, an interested person could initiate a scientific peer review to evaluate whether the agency failed to exercise reasonable precautionary guidelines. To guard against overuse of either procedure, the results and findings of the peer review would be entitled to great deference in any judicial review proceeding of the agency's final decision. This would leave the Professional Judgment Method in its appropriate position as the default methodology for ESA decisions, but allow the Scientific Method and Precautionary Principle Method a role in difficult cases.

I. INTRODUCTION

II. GenERAL FrameworkS For DECIDING How to DECIDE................................................563

A. Level of Confidence Framework ........................................................................ 563

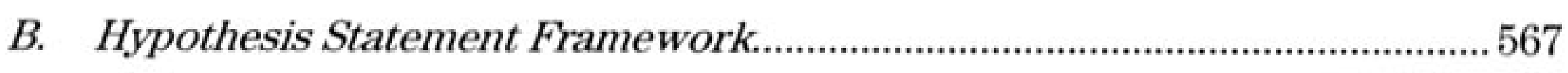

C. Error Aversion Framework ……...................................................................... 570

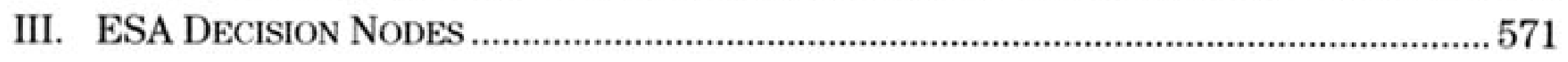

IV. Three Competing Modeis of ESA Methodology ..................................................... 576

A. The Professional Judgment Method-Working With the "Best

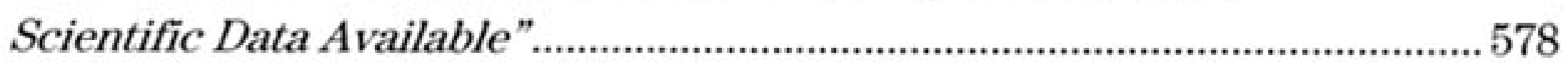

B. The Scientific Method-Emphasis on "Best Scientific Data ... "................. 584

C. The Precautionary Principle Method-Emphasis on "Best ... Data Available".

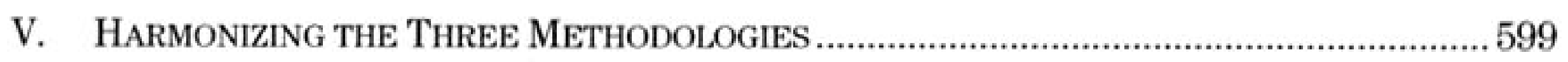

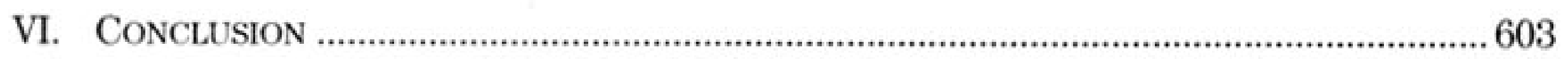




\section{INTRODUCTION}

The substantive contours of the Endangered Species Act $(E S A)^{1}$ have been largely worked out for quite some time. Congress, now virtually inert when it comes to environmental law reform, has not touched the ESA in any meaningful way for over two decades. ${ }^{2}$ Likewise, with the exception of the Habitat Conservation Plan permit program under section 10 of the statute, ${ }^{3}$ neither of the agencies authorized to implement the ESA has engaged in substantive legislative rulemaking for many years. With so little movement on the statutory and regulatory fronts, by the early 1990s the courts had settled most of the substantive interpretation questions. The political reality is that the substantive law of the ESA is not likely to budge for the foreseeable future. Nevertheless, litigation under the ESA and calls for statutory reform abound, seeming to increase in volume and intensity with each passing year.

One source of this burgeoning wave of litigation and lobbying is a battle over ESA methodology - the principles and rules of organization for the inquiry processes necessary for making decisions required under the statute. ${ }^{4}$ The ESA requires the Secretary of the Interior, who acts through the Fish and Wildlife Service (FWS), and the Secretary of Commerce, who acts through the National Marine Fisheries Service (NMFS), to make various decisions about the status and protection of animal and plant species. ${ }^{5}$ In suits brought by citizens alleging FWS or NMFS has failed to meet its statutory mandates,${ }^{6}$ courts have been willing, almost eager, to find FWS and

1 Endangered Species Act of 1973,16 U.S.C. $\$ \S 1531-1544$ (2000). This Article is not intended to provide a comprehensive overview of the ESA. Rather, it focuses attention on programs and features of the statute for which questions of methodology bear particular importance. For comprehensive treatments of the ESA, several of which are referred to frequently infra, see LAWRENCE R. LIEBESMan \& Rafe PETERSEn, Holland \& KNiGHT LLP, Endangered Species DeskbooK (2003); Endangered Species ACT: Law, Policy, and PERSPECTIVEs (Donald C. Baur \& Wm. Robert Irvin eds., 2002) [hereinafter LAW, PoliCY, AND Perspectives]; Stanford EnVIRonmental Law Society, The Endangered Species ACt (2001) [hereinafter SELS]; Tony A. Sullins, Endangered Species ACT (2001); Michael J. BEAN \& MELANIE J. ROWLAND, THE EVOLUTION OF NATIONAL WILDLIFE LAW (3d ed. 1997).

2 Amendments to the ESA in 1988 were minor in scope. See Endangered Species Act Amendments of 1988, Pub. L. No. 100-478, 102 Stat. 2306 (making minor changes throughout the Act, but notably increasing civil penalties and authorizing appropriations to carry out the purposes of the Act). The last set of amendments to make substantial changes to the statute was enacted in 1982. See Endangered Species Act Amendments of 1982, Pub. L. No. 97-304, 96 Stat. 1411 (altering procedures for listing species). For a concise history of the enactment of the ESA and its subsequent amendments, see SELS, supra note 1, at 14-26.

3 See infra notes 44,64 and accompanying text.

4 This is to be distinguished from the rules of administrative procedure, such as how rules are promulgated and hearings and public comment processes are conducted.

5 See 16 U.S.C. $\S 1532(15)$ (2000) (defining "Secretary"); 50 C.F.R. $\$ \S 424.01-.21$ (2003) (FWS and NMFS joint regulations). FWS generally is responsible for terrestrial and freshwater species, while NMFS is responsible for marine and anadromous species. NMFS, a division of the National Oceanic and Atmospheric Administration, is also known as NOAA Fisheries.

${ }^{6}$ Like many federal environmental laws, the ESA contains a provision allowing citizens to sue federal agencies for failure to carry out nondiscretionary duties under the statute. 16 U.S.C. $\S 1540(\mathrm{~g})(2000)$. 
NMFS at fault for procedural errors, such as missing decision deadlines, ${ }^{7}$ but until recently it was unusual for courts to find that the agencies had made substantive errors in their decisions about the status and protection of species. The conventional rules of judicial review tilt the balance decidedly in favor of the agencies in litigation challenging the substantive merit of the agencies' decisions. $^{8}$ This judicial deference, plus the fact that the substantive statutory and regulatory context was locked in place, made it far more likely than not that FWS and NMFS decisions would be upheld on the merits. $^{9}$

This aura of immunity carried the agencies well into the 1990 s before it began to crumble. Starting in the mid-1990s, opponents of FWS and NMFS decisions from both the industry and the environmental camps realized that the methodological contours of the ESA were not nearly as settled as their substantive kin. It was quite clear, for example, what substantive factors the agencies had to consider in order to designate the "critical habitat" of a species protected under the ESA. ${ }^{10}$ However, it was far less clear at the time just exactly how the agency was supposed to consider those factors-how to collect the evidence, how to evaluate the evidence, how to weigh the evidence, and how to reach a conclusion. Quite obviously, methodological rules of this sort can have a profound impact on substantive decision outcomes. The fact that they were not clearly worked out under the ESA, therefore, presented stakeholders an opportunity to influence substantive decision-making outcomes without having to alter the substance of the law or challenge the substantive merits of discrete agency decisions. Thus, the debate began in the late 1990s and has been going strong since then, reflecting the realization industry and environmental interests must have made - that how these methodological rules develop could revolutionize the ESA for decades to come. ${ }^{11}$

${ }^{7}$ For example, the requirement that FWS and NMFS designate "critical habitat" of listed species has in recent years been the subject of tremendous controversy regarding the agencies' failure to complete designations for many listed species. Critical habitat is to be designated concurrently with the final listing rule unless the listing agency decides that the listing action should not be delayed while the critical habitat designation is being completed, or that additional time of up to one year is needed to make the necessary biological and other determinations relating to critical habitat. Id. $\$ 1533(\mathrm{~b})(6)(\mathrm{C})(\mathrm{ii})$. The listing agency can decline to designate critical habitat if it finds that designation would not be prudent. Id. Courts generally have held FWS and NMFS strictly to those deadlines. See, e.g., Natural Res. Def. Council v. United States Dep't of the Interior, 113 F.3d 1121, 1127 (9th Cir. 1997) (limiting the use of imprudence exemption).

8 See infra note 27 and accompanying text.

9 For example, it was not until 1988 that a court found that either of the agencies had erred on the merits in a decision whether to list a species as endangered or threatened. See N. Spotted Owl v. Hodel, 716 F. Supp. 479, 483 (W.D. Wash. 1988) (requiring FWS to fully address expert opinion, not simply its own conclusory expertise-based assertions, in determining listing status).

10 See infra notes 51-52 and accompanying text.

11 For example, the critical habitat issue mentioned in the text was recently the subject of litigation challenging the approach FWS took to evaluating the critical habitat criteria in the case of an endangered owl. See Home Builders Ass'n of N. Cal. v. United States Fish \& Wildlife Serv., 268 F. Supp. 2d 1197, 1235-36 (E.D. Cal. 2003) (vacating a designation of critical habitat 
This Article explores the breadth and depth of the ensuing battle over ESA methodology. Section II lays out the framework for evaluating decisionmaking methodologies. One basis on which we might choose how to go about making decisions is the level of confidence we wish those decisions to enjoy. If we want to be as sure as possible that a decision is correct, we would subject it to rigorous empirical tests through a process I (being far from the first) will call the Scientific Method. Where the costs of the Scientific Method are not justified, or the data needed to complete it are unavailable, we might feel comfortable relying on experts in fields relevant to the subject matter of the decision, whose experience and expertise we believe will allow them confidently to fill in the gaps that prevent competent use of the Scientific Method. This methodology, which I will call the Professional Judgment Method, prevails in administrative law. There may be times, however, when the evidence points to a particular decision under either of the two previous methodologies, but the consequences of the decision turning out to be wrong are so severe that we want to exercise caution by resisting the weight of the evidence. This fear of mistakes and their consequences motivates what I will call the Precautionary Principle Method. The more confidence we wish to have in a decision being correct, the more we will eschew the Precautionary Principle Method and gravitate toward the other two methods.

Of course, it is hard for anyone to decide which methodology to use until more is known about the nature of the decision that has to be made. For scientists testing cause-and-effect relationships between physical phenomena, the Scientific Method prescribes a manner for stating and testing relevant testable hypotheses. Agencies, by contrast, are handed their "hypotheses" through statutory directives. The way Congress expresses the findings an agency must make in order to take prescribed action will influence how different interested stakeholders form preferences for different methodologies of decision making. For example, one possible hypothesis to test under the ESA is "the species is endangered." In that case, using the Scientific Method would require more rigorous justification of the decision that the species is in fact endangered than would the other methodologies. An advocate for species protection thus might object to using the Scientific Method in that context. But if the hypothesis used for ESA purposes were "the species is not endangered," the Scientific Method would cut in favor of anyone interested in increasing species protection. The burden of proof the Scientific Method imposes has substantive effect depending on the hypothesis to be proved. So, how we frame hypotheses will influence who favors a particular methodology.

This dichotomy between hypothesis statements reveals another framework for methodology selection-aversion to mistaken conclusions about whether the hypothesis is true. Say we are testing the hypothesis that two observed variables are related in some way. The Scientific Method is designed to weed out what is known as "alpha" or "Type I" error-the

based primarily on what can be characterized as methodological flaws). For details, see infra notes 110-18. 
identification of a causal relationship between the two variables when one does not exist. ${ }^{12}$ The other kind of error, "beta" or "Type II," involves the finding of no causal relationship when one in fact does exist, and is precisely what the Precautionary Principle Method is intended to guard against. The Professional Judgment Method imposes no particular risk aversion bias, asking that the experts decide how best to balance the risk portfolio. Hence, we may prefer one of the methodologies based on how we wish to manage risk.

Because methodology selection depends so much on how hypotheses are stated and the risk aversion bias of different interest groups, Section III provides some background on the ESA and its numerous decision-making nodes-the points at which a choice among the three methodologies must be made using one or more of the frameworks discussed above. Three features of the ESA make its decision-making context particularly susceptible to fights over methodology. First, many decisions the agencies must make involve questions of biological science for which the available scientific database is either sparse or inconclusive. By demanding that the agencies nonetheless reach conclusions under strict deadlines, the ESA sets up a methodological quandary. Second, these biological evaluations often arise in legal contexts that present a poor fit between science and policy. The decisions the law demands the agencies make, in other words, often do not make sense to a scientist. Finally, ESA decisions are characterized by the intense involvement of viciously combative interest groups willing to sue each other and the agencies with what appears to be gleeful abandon. Where the opportunity presents itself to shape ESA methodology, the opposed interest groups seem happy to litigate to a pitched battle in short order.

Section IV of the Article frames and assesses the battle positions, which fall into three competing methodological camps. None of the frameworks for choosing methodologies leads to a particularly compelling result under the ESA. By default, the ESA had, until the mid-1990s, followed a fairly conventional methodology for making decisions: the agencies implemented substantive duties based largely on the Professional Judgment Method, for the most part unshackled by significant method constraints, with their decisions subject to judicial review under the deferential Administrative Procedure Act ${ }^{13}$ standards. ${ }^{14}$ Not surprisingly, FWS and NMFS cling dearly to the Professional Judgment Method.

Two alternative themes have emerged, however, to alter the settled practice. Not surprisingly, they would pull the statute in opposite directions and thus are well represented in public debate over how to implement the ESA. Industry's theme is science, or at least a postulated version of the Scientific Method, which would render ESA decision making more like Ph.D.

12 See National Research Council, Science AND the Endangered Species Act 162-67 (1995) [hereinafter SCIENCE AND THE ESA] (describing the types of statistical errors and their effects on ESA listing process). For elaboration on error types, see infra notes 34-37 and accompanying text.

135 U.S.C. $\$ \$ 551-559,701-706,1305,3105,3344,4301,5335,5372,7521$ (2000).

14 See infra notes 74-80 and accompanying text (describing review under these standards). 
dissertation defenses. Under this approach, an agency decision to extend protection to a species, such as by limiting land development in the species' habitat, would have to withstand the rigors of a scientific peer review process assessing each facet of the agency's work under Scientific Method principles. The environmental groups' alternative to peer review and other accoutrements of science is to err on the side of the species, an approach embodied in the Precautionary Principle Method. Under this method, all close calls are resolved in favor of extending protection to a species, even when the evidence in support of protecting a species is slim, sufficient at most to support a fear that failure to protect the species could have adverse consequences.

The three methodologies incorporate starkly different approaches to risk management relating to species conservation. By demanding rigorous empirical testing and confirmation of the hypothesis (in the ESA context, that protection of the species is warranted), and subjecting the presentation of findings and conclusions to peer review, the Scientific Method hopes to reduce Type I error in the form of unjustified protection of species. By calling for protective action without undergoing the complete battery of Scientific Method tests, the Precautionary Principle Method hopes to reduce Type II error in the form of underprotection of species. The Professional Judgment Method adopts neither of these risk aversion biases, allowing experts to weigh available evidence and use their professional experience to decide how best to balance the portfolio of error possibilities for a particular species protection decision. By locking in aversion to Type I or Type II error as the default rule, therefore, the Scientific Method and Precautionary Principle Method represent a dramatic change of affairs for the ESA, the agencies that implement it, the people who live under it, and the species protected by it. By changing the decision-making constraints, in other words, either of these methodologies would create an altogether different universe of substantive outcomes.

Yet close examination reveals neither of the postulated alternatives to the Professional Judgment Method finds support in the statutory framework of the ESA. To be sure, each enjoys strong appeal in ESA policies that, ironically, are themselves in conflict. On the one hand, the ESA is about science-based decisions, so why should the Scientific Method not play an important methodological role? But the ESA is also about protecting species on the brink of extinction. Should precaution not dictate methodological approaches for species in peril of vanishing from the planet? Interesting questions for an academic, but the question for the courts is not what methodology Congress should have adopted, but what methodology it did adopt. The best answer is that the ESA clearly requires neither the Scientific Method nor the Precautionary Principle. It is also likely that the statute provides the agencies some latitude, in their exercise of the Professional Judgment Method, to adopt techniques of the Scientific Method and Precautionary Principle Method as means of testing for and guarding against Type I and Type II errors. But it is less clear how far the agencies' discretion would allow them to move in either direction-that is, to adopt the Scientific 
Method or Precautionary Principle Method as the dominant method for ESA implementation.

Given this ambiguity, the discussion inevitably must return to the "should have" question-i.e., what should Congress and the agencies do about ESA methodology? Existing political configurations make it highly unlikely that Congress or the agencies would imprint the Precautionary Principle Method onto the ESA, and for that I am glad. The Precautionary Principle Method, if unleashed as environmental groups envision it, would wreak economic havoc under the ESA and, with little more than "caution" as the pretext for species protection, would severely reduce the statute's legitimacy from its already tenuous status. On the other hand, political conditions do favor strong movement in the direction of "sound science" reform of the ESA, and for that I am concerned. The Scientific Method, if implemented wholesale across ESA programs, as many industry interests have advocated, would severely undermine species protection efforts. In short, while in hindsight we may detect errors made in application of the Professional Judgment Method, the costs of replacing it with either the Scientific Method or the Precautionary Principle Method as the ESA methodology far outweigh any error-correcting advantages they may provide.

Nevertheless, there are times when the Scientific Method and the Precautionary Principle Method should have a role to play under the ESA, sometimes even hand-in-hand. The challenge is to design a framework that both gives these methods a role and keeps them under control. Section V of the Article outlines a proposal to create a procedure under which FWS and NMFS could elect to adopt the Precautionary Principle Method in discrete decision-making instances based on a finding that a significant risk of Type II error with severe consequences exists in connection with a decision not to extend protection to a species. Any interested person could then require the agency to obtain a rigorous scientific peer review of the basis for the agency's decision as means of checking against irrational precaution. Conversely, the proposal would also establish a process under which any interested person could petition a standing committee of scientists to decide whether to require a scientific peer review upon finding that the agency may have failed to exercise reasonable precautionary guidelines. To guard against overuse of either procedure, the results and findings of the peer review would be entitled to great deference in any judicial review proceeding of the agency's final decision. This would leave the Professional Judgment Method in its appropriate position as the default methodology for ESA decisions, but allow the Scientific Method and Precautionary Principle Method a role in difficult cases.

Methodology matters. Hence, we should strive to improve the decisionmaking approaches of administrative agencies. That is the spirit of my proposal. To be sure, neither the question of methodology, nor the quest for the best fit, are unique to the ESA. ${ }^{15}$ Yet the ESA presents them in the

15 See Holly Doremus, Listing Decisions Under the Endangered Species Act: Why Better Science Isn't Always Better Policy, 75 WASH. U. L.Q. 1029, 1033-35 (1997) (discussing 
sharpest of contexts, pitting human enterprise against the fate of entire species. One would think, therefore, that the search for the most productive methodological fit for the ESA would be undertaken in earnest by all who have an interest in the promise of species conservation-it should be a model for all other such journeys. What I find in the battle over ESA methodology, however, is mostly rhetoric, intended to disguise efforts to shift the substantive playing field. I dare say that many advocates of using the Scientific Method in the ESA would not know it if they saw it, and many proponents of employing the Precautionary Principle Method at every turn for the ESA are chronic Chicken Littles. It is time to move past these facades and open a genuine discourse on ESA methodology.

\section{GENERAL FrameworkS FOR DECIDING How TO DECIDE}

People place a lot of stock in their "gut instinct" when making personal decisions. People choose mates, buy houses, pick stocks, and make all sorts of other vital professional and personal decisions based on their guts. "Playing it safe" is another common explanation people offer for their personal decisions. Furthermore, if we want to really run a decision through the wringer, there is the sheet of paper on which we list "pros" on one side and "cons" on the other. There is no shame in using any of these decisionmaking methods; indeed, people boast of the predictive powers of their guts and are happy to debate the pros and cons for hours.

What is good enough for people, however, may not be good enough for federal agencies making decisions with sweeping socioeconomic ramifications. I doubt we would tolerate a federal agency openly saying it made such a decision based on its "gut instincts," or just "because it wants to," and leaving it at that. We expect more of agencies, but how much more? There are several frameworks we can employ, separately or together, to assist in deciding that question. One focuses on the level of confidence we seek in the agency's decisions. Another focuses on the kind of questions the agency is required to ask under the particular regulatory program the agency administers. A third focuses on the kind of decision error we seek to minimize.

\section{A. Level of Confidence Framework}

As stakeholders examine an agency's decision, they are likely to evaluate it based on some function of the volume and direction of evidentiary data the agency proffers in support of the decision. Confidence in the agency's decision, in other words, is directly proportional to the measure of a combination of the volume and direction of the evidence. We routinely apply different terms as representations of the bases for decisions made at different points along this spectrum. Thus, where the volume and direction of evidence are both very much against the decision, we would call the basis for the decision nothing short of sheer arrogance. Where, on the 
other hand, data are plentiful, all are thoroughly tested, and all point clearly in the direction of the decision, we might go so far as to say that the decision finds support in the familiar Scientific Method, which is defined by the use of empirical observation and experimental testing to formulate and evaluate hypotheses, usually about causal mechanisms, with which to predict phenomena, such as "significantly more degradation of species $x$ 's habitat will lead to the extinction of species $x .{ }^{16}$ In between those two poles, we can apply other representations of possible decision grounds, as suggested in the following figure:

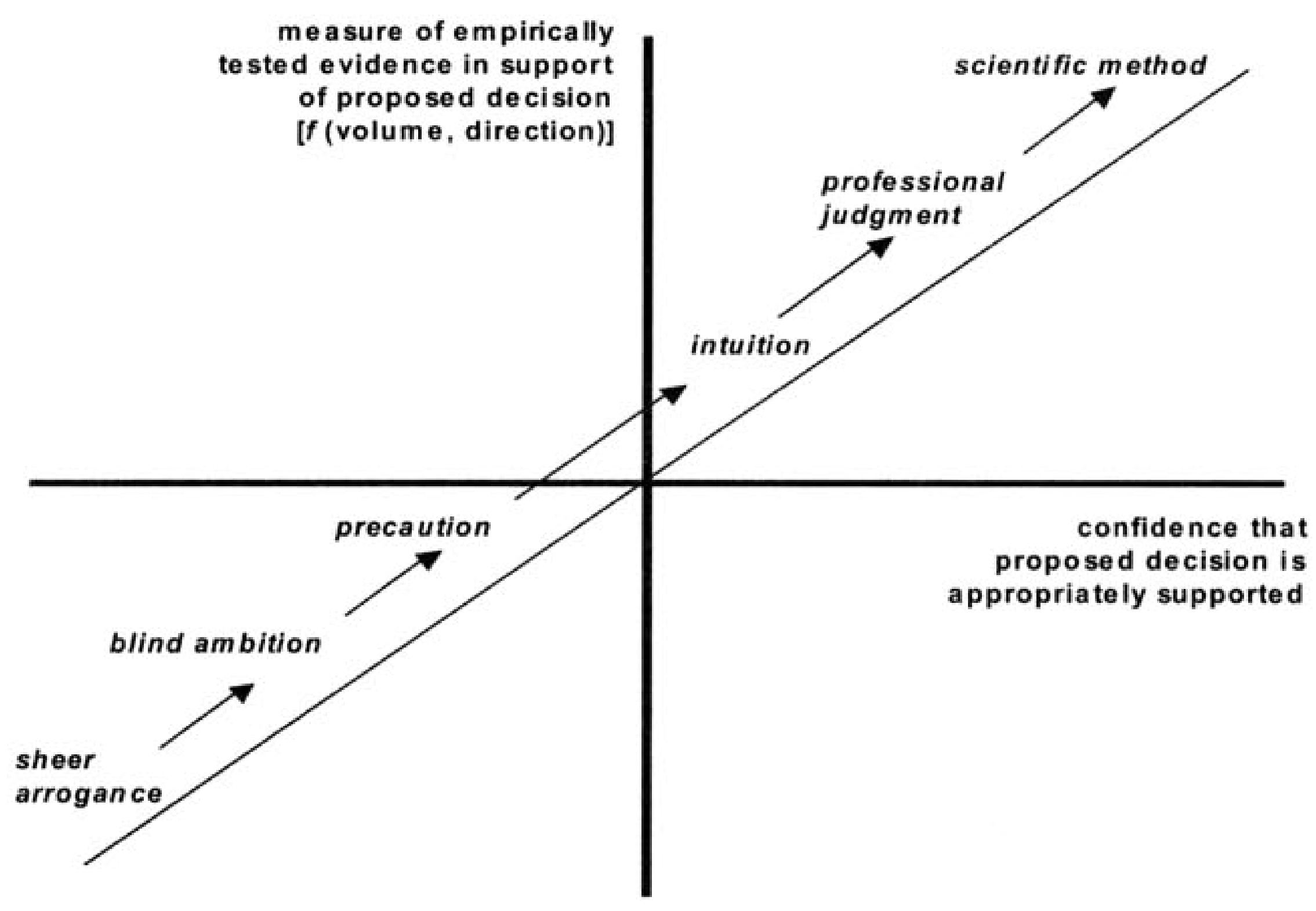
BASES FOR JUSTIFYING DECISIONS AS A FUNCTION OF
DIFFERING LEVELS OF EVIDENCE IN SUPPORT

All other things being equal, we could expect to find broad agreement among the public and the agencies that decisions ought to be based on

16 Holly Doremus provides a concise summary of the Scientific Method:

Procedurally, science is a formalized system for gathering and evaluating information about the world. Its essential steps are observation, communication, informed criticism, and response. A scientist gathers data through observation or experimental manipulation. She then communicates those data, together with an explanation of the methods used to gather them, to the community of scientists in her field. The scientific community reviews and critiques the work, commenting in ways that may inspire the original scientist and others to seek additional data or alternative explanations.

Doremus, supra note 15, at 1057. For elaboration on the Scientific Method generally, see infra Section II.B. For a more extensive discussion of the Scientific Method in the context of species status evaluations, see Doremus, supra note 15, at 1087-1129. 
methods as far along the spectrum toward the Scientific Method as possible. But any scientist will tell you that this is a state rarely achieved even in wellfunded research institutions-particularly in cases where research depends on observation of species in the field, certainty is the scientific equivalent of nirvana. ${ }^{17}$ Even more so, any agency official will tell you that agencies rarely have the time, resources, or clear mandate to reach that level of confidence even if it were scientifically possible. ${ }^{18}$ It takes time and money to do science.

As for the other end of the spectrum, we hope that our system of transparent government and judicial review in the administrative state is capable of smoking out cases of decisions supported by nothing more than sheer arrogance or blind ambition. Such motivations may suffice for legislative decisions, but the familiar "arbitrary and capricious" and "substantial evidence" standards of judicial review are geared principally toward weeding out such behavior in agencies. ${ }^{19}$

What about precaution and intuition? These emotions motivate use of the Precautionary Principle Method. Although many syntactic versions of the precautionary principle exist throughout the laws of many nations and in the text of many international treaties, ${ }^{20}$ a useful prototype is found in Principle 15 of the 1992 Rio Declaration of the United Nations Conference on Environment and Development:

In order to protect the environment, the precautionary approach shall be widely applied by the States according to their capabilities. Where there are threats of serious or irreversible damage, lack of full scientific certainty shall not be used as a reason for postponing cost-effective measures to prevent environmental degradation. ${ }^{21}$

Ignorance, in other words, should not justify the decision either to move forward with a proposed action that might threaten the environment,

17 See Doremus, supra note 15, at 1069-71 (discussing the limits of reliability in the biological sciences).

18 See SCIENCE AND THE ESA, supra note 12, at 157-71 (discussing the complex nature of ESA decisions).

19 See Motor Vehicle Mfrs. Ass'n v. State Farm Mut. Auto. Ins. Co. (State Farm), 463 U.S. 29, 34 (1983) (holding the revocation of Motor Vehicle Safety Standard 208 arbitrary and capricious where agency "failed to present an adequate basis and explanation"). For discussion of the judicial review standards applied in the ESA context, see infra notes 89-96 and accompanying text.

20 See Christopher Stone, Is There a Precautionary Principle?, 31 Envtl. L. Rep. (Envtl. L. Inst.) $10,790,10,790-91$ (July 2001) (providing examples).

21 Rio Declaration on Environment and Development, UNCED, U.N. Doc. A/CONF.151/Rev. 1, 31 I.L.M. 874, 879 (1992). There are numerous variations on this theme, with different emphases on the level of risk, the type of harm, the degree of uncertainty, and the character of the response. It is not within the scope of this Article to review all such variations. For extensive discussions of the history, justification, and implementation of the precautionary principle, see Protecting PUBlic Health \& THE ENVIRONMENT: IMPLEMENTING THE PRECAUTIONARY PRINCIPLE (Carolyn Raffensperger \& Joel Tickner eds., 1999) [hereinafter Implementing the PrecautionaRy PRinciple] and Perspectives on the Precautionary PRINCIPLE (Ronnie Harding \& Elizabeth Fisher eds., 1999). 
or not to regulate an activity on behalf of the environment. ${ }^{22}$ Clearly, "[t]his idea is supposed to run counter to standard decision-making procedures (e.g., cost-benefit analysis), in which possible but unproven causal connections do not count." ${ }^{23}$ On the other hand, though our parents teach us to be careful (or we might poke out an eye), precaution taken to the extreme in regulatory contexts could lead to decision paralysis. Thus my rationale for placing precaution below intuition on the sliding scale of decision grounds: precaution may be motivated by over-cautious behavior not justified by good judgment or sound intuition. This, indeed, is the challenge for advocates of the Precautionary Principle Method-i.e., to develop a more structured basis for demonstrating that precaution is the better exercise of judgment in discrete regulatory decision-making settings where the weight of the evidence may indicate otherwise.

Intuition alone will usually not suffice in that regard. Intuition, while often prompting action or caution, is simply the technical term for "gut instinct." Intuition should not be ignored, but the prospect of administrative agencies making significant decisions based on intuition alone is "not a comfortable idea." 24 Rather, intuition is usually expected to lead decisionmaking bodies to something more substantial as a basis for agency action rather than to supply an independent and sufficient ground for decision. ${ }^{25}$

That something more is the considered, well-reasoned, deliberative decision supported by the professional experience, learning, practice, and expertise relevant to the subject matter of the agency's decision-in other words, the agency's professional judgment. Although, like the precautionary principle, definitions of professional judgment are imprecise, Congress has supplied one for administrative agency purposes:

a finding, determination or decision that is consistent with principles of sound... management and administration, available science and resources, and adherence to the requirements of this Act and other applicable laws. ${ }^{26}$

22 See Gail Charnley \& E. Donald Elliott, Risk Versus Precaution: Environmental Law and Public Health Protection, 32 Envtl. L. Rep. (Envtl. L. Inst.) 10,363, 10,363 (2002) ("Support for the precautionary principle is motivated in part by a desire for a more agile legal system that does not use incomplete science as a reason to postpone regulating.").

23 Neil A. Manson, Formulating the Precautionary Principle, 24 EnvTl. ETHICs 263, 264 (2002); see also Charnley \& Elliott, supra note 22, at 10,364 ("The rise of the precautionary principle can be viewed as an objection to the U.S. legal tradition of extensive administrative law requirements and court review of the factual basis of government decisions about environmental risks.").

24 Cent. Fla. Enters., Inc. v. Fed. Communication Comm'n, 598 F.2d 37, 59 (D.C. Cir. 1978). See also Bechtel v. Fed. Communication Comm'n, 10 F.3d 875, 887 (D.C. Cir. 1993) (explaining that when reaching decisions about successful license applicants, "any effort to rely on intuitive judgments about applicants, assuming Commissioners had sound intuition, would provide rich opportunities for graft and corruption in a public agency dispensing valuable resources"); Garrison v. Heckler, 765 F.2d 710, 714 (7th Cir. 1985) (recognizing that the use of agency intuition when making decisions about disability could lead to disparate agency decisions).

25 See Doremus, supra note 15, at 1063-65 (discussing how scientists use hunches and intuition to lead to further scientific inquiry).

26 National Wildlife Refuge System Administration Act of 1997,16 U.S.C. $\S 668 e e(3)$ (2000). 
The upshot is that, in practical reality, most agencies operate by hoping to convince the courts and the public that they have exercised something in the decision-making realm of sound professional judgment. To be sure, there may be plenty of arrogance, ambition, precaution, and intuition at play as well, but professional judgment has the right ring to it. It is the level of confidence to which most of the administrative state has grown accustomed.

Much of the methodological debate in administrative law simply boils down to the question of how low on the decision grounds hierarchy we are willing to tolerate the agency sinking to justify its decisions. In general, the conventional judicial review framework in place under most environmental laws tolerates decisions based on the agency's professional judgment and seldom demands more. ${ }^{27}$ Although ambition and arrogance do not necessarily lead to wrong decisions, no legitimate administrative decisionmaking framework tolerates decisions that explicitly use those methods or which can show no other basis for decision. Thus, a main function of conventional judicial review is to weed cases of blind ambition and sheer arrogance out of a system built around the Professional Judgment Method.

The relevant spectrum for purposes of policy choices about the appropriate agency decision-making methodology, therefore, is from the Precautionary Principle Method at the low end to the Scientific Method at the high end, the question being how far in either direction to deviate from the Professional Judgment Method. The Scientific Method would force agencies to operate farther up the hierarchy, making even professional judgment insufficient as a basis for decision. At the other extreme, the Precautionary Principle Method would require that courts tolerate agencies sliding down the scale, using intuition and precaution to guide decisions even to the point of acting against the grain of evidence in order to guard against perceived adverse consequences of mistaken decisions. The Professional Judgment Method, which dominates and can be thought of as the default position, is somewhere in between.

\section{B. Hypothesis Statement Framework}

The level of confidence framework does not tell us all we may want to know when choosing an administrative decision-making methodology. One

27 See, e.g., Natural Res. Def. Council, Inc. v. Muszynski, 268 F.3d 91, 102 (2d Cir. 2001) (stating that absent a methodology imposed by statute, the agency is entitled to use "best professional judgment"); Davis v. Slater, 148 F. Supp. 2d 1195, 1203 (D. Utah 2001) ("With regard to review of the scientific determinations on the record, courts give deference to the agency's special expertise and professional judgment."), order denying preliminary injunction rev'd sub nom. Davis v. Mineta, 302 F.3d 1104 (10th Cir. 2002); S. Utah Wilderness Alliance v. Babbitt, No. $2: 99 \mathrm{CV} 852 \mathrm{~K}, 2000 \mathrm{WL} 33347722$, at *3 (D. Utah 2000) ("Judicial deference to agency discretion is particularly appropriate when decisions are based on the agency's special expertise and professional judgment."); Grant Assocs., Inc. v. United States, $11 \mathrm{Cl}$. Ct. 816, 830 (1987) (“[T]he court will not substitute its judgment for that of the expert agency in areas involving informed discretion and professional judgment."). The foundation for this deference rests on the theory of the administrative agency as a repository of expertise. See Marsh v. Or. Natural Res. Council, 490 U.S. 360, 378 (1989) (noting that an agency "must have discretion to rely on the reasonable opinions of its own qualified experts"). 
also has to consider the nature of the decision in which we are seeking confidence. For example, scientists conducting pure research on physical cause-and-effect relationships must develop a hypothesis to be tested. ${ }^{28}$ When inquiring about the relationship between two variables-for example, the loss of habitat and the decline of a species' population-the Scientific Method uses statistical analysis of observed empirical data to test what is known as the "null hypothesis," which postulates that there is no relationship. The "alternative hypothesis," that there is a relationship, is of more interest because its proof may lead to further inquiry and improved understanding of physical and biological phenomena. However, only if the statistical tests show with a high level of confidence-usually taken to mean a $95 \%$ level of statistical confidence-that the null hypothesis is wrong will the Scientific Method accept the alternative hypothesis.

There is nothing normative about this approach as a method of inquiry-it simply is the way the Scientific Method is performed. By contrast, in administrative contexts such as the ESA, Congress specifies an agency's "hypotheses" through statutory directives about the findings the agency must make in order to take action. This "action hypothesis" statement function of statutes is driven by the legislature's normative concerns and extends to a broad range of agency actions, such as the exercise of jurisdiction, the decision whether a proposed activity requires a permit, and the decision whether to grant such a permit. The problem is that Congress might state the action hypothesis in a way that flips the way the null and alternative hypotheses are usually stated under the Scientific Method. Congress might, for example, instruct an agency to regulate a chemical if it finds that its unrestricted use will significantly injure the environment. Conversely, Congress might require an agency to regulate a chemical unless it finds that its unrestricted use will not significantly injure the environment. In the first instance, the agency's action hypothesis-the finding that it must make to take action-is that the unrestricted use of the chemical will significantly injure the environment. In the second instance, however, the statute has reversed the hypothesis, and in order to decide not to regulate, the agency must find that the unrestricted use of the chemical will not significantly injure the environment.

Although these two hypotheses may seem like two sides of the same coin, the various normative positions different stakeholders in the regulatory program exhibit will lead them to prefer different methodologies depending on how Congress structures the agency's action hypothesis. Say, for example, that Congress has chosen the latter action hypothesis, requiring the agency to regulate the chemical unless it finds that its unrestricted use will not significantly injure the environment. A person who prefers that the chemical be regulated will favor subjecting that action hypothesis to the Scientific Method-i.e., requiring the agency, in order to decide not to regulate, to amass a convincing scientific case that the unrestricted use of the chemical will not significantly injure the environment. By contrast,

28 For a more detailed version of this explanation of how hypotheses are formulated in the Scientific Method, see SCIENCE AND THE ESA, supra note 12, at 162-63. 
someone who wishes to see the chemical remain unregulated would prefer that a lower threshold of proof apply, as in the Precautionary Principle Method, so that the agency could make the finding not to regulate based on less compelling evidence, presumably to guard against unnecessarily losing the benefits of unrestricted use of the chemical. The agency, most likely, would prefer to maximize its discretion by being allowed to operate under the Professional Judgment Method.

An important point to be made from the foregoing is that the Precautionary Principle Method, like the Scientific Method, is not normative in origin or orientation; rather, it is simply a decision-making method that, again like the Scientific Method, relies on information derived from scientific inquiry, but differs in the way it uses that information to make decisions. ${ }^{29}$ In other words, it is the decision to use the Precautionary Principle Method, not the method itself, which is normative in motivation. ${ }^{30}$ To be sure, "the precautionary principle" has become associated with "environmentalism," particularly in international circles, ${ }^{31}$ and "environmentalists" have often wrapped it in normative clothing. ${ }^{32}$ But this strong association between environmentalism and advocacy of the Precautionary Principle Method is largely the result of how Congress has stated environmental agencies' decision hypotheses-i.e., that, generally speaking, agencies cannot regulate unless they establish a relationship between the activity for which regulation is sought and some form of environmental harm within the agency's jurisdiction. ${ }^{33}$ As the foregoing example illustrates, however, by changing the decision hypothesis to say an agency must regulate unless it finds no harm, the methodology preferences of "environmentalists" and "industrialists" would turn 180 degrees! We would see environmental protection interests arguing for more science, and industry and development interests arguing for more precaution, only in the latter case it would be precaution on behalf of preventing unwanted socioeconomic consequences of overregulation. And the agency would, as usual, prefer to operate under the more neutral and flexible Professional Judgment Method.

29 See David Santillo et al., The Precautionary Principle in Practice: A Mandate for Anticipatory Preventative Action, in Implementing the Precautionary Principle, supra note 21 , at 36,45 ("[T] that one uses science while the other does not, but simply the way in which scientific evidence is employed for decision making at the science-policy interface.").

${ }^{30}$ Most methodology choices in regulatory systems are inherently normative in aspect. See generally Matthew D. Adler, Risk, Death and Harm: The Normative Foundations of Risk Regulation, 87 MINN. L. REv. 1293 (2003).

31 See David A. Dana, A Behavioral Economic Defense of the Precautionary Principle, 97 Nw. U. L. REv. 1315, 1315 (2003) (“[V]irtually every recent international environmental agreement invokes this principle.").

32 See, e.g., John S. Applegate, The Taming of the Precautionary Principle, 27 WM. \& MARY ENVTL. L. \& POL'Y REV. 13, 74-77 (2002) (arguing for a revitalized precautionary principle as a core element of environmental law).

33 See Charnley \& Elliott, supra note 22, at 10,364 (noting that, as used by environmental protection advocates, the precautionary principle "challeng[es] a core premise of the American legal culture that requires an extensive factual record to justify government regulatory action"). For a discussion of this style of action hypothesis in the ESA context, see infra notes 71-72 and accompanying text. 


\section{Error Aversion Framework}

The foregoing example reveals the third framework for choosing methodologies - risk aversion, or, more to the point, mistake aversion. There are two kinds of mistakes we risk making whenever we draw a conclusion about a cause-and-effect relationship. ${ }^{34}$ On the one hand, we might find after conducting all the statistical tests we can imagine that the rigors of the Scientific Method lead us to reject the null hypothesis, when in fact it is true. This would mean, in other words, that we accept the alternative hypothesis that there is a relationship between the variables under study, when in fact there is not. This is called "alpha," or "Type I," error, also known more familiarly as a "false positive." Of course, there is the converse to be considered. We might conclude under the strict guidelines of the Scientific Method that the null hypothesis should be accepted, when in fact it is false. In this case, we would have mistakenly claimed no relationship between the variables exists when in fact one does. This is called "beta," or "Type II," error, or a "false negative."

What distinguishes the Scientific Method from the Precautionary Principle Method is the type of error to which the method is most averse. The Scientific Method is loath to conclude that a cause-and-effect relationship exists without a high level of confidence. In other words, the Scientific Method is most averse to Type I error, and thus demands high levels of confidence to accept the hypothesis that variables $X$ and $Y$ have some cause-and-effect relationship. ${ }^{35}$ By contrast, the Precautionary Principle Method is most concerned about avoiding Type II error, and thus would forego the high level of confidence the Scientific Method requires to accept the action hypothesis in order to guard against its mistaken rejection. ${ }^{36}$ Considering the hypothesis statement and error aversion frameworks together, therefore, the two approaches can be compared as follows: ${ }^{37}$

34 For a more detailed discussion of this explanation of risk aversion and types of error, see SCIENCE AND THE ESA, supra note 12, at 165-67.

35 See id. at 167 ("Scientists are trained to minimize the probability of making the first error, that is, rejecting a null hypothesis when it is actually true.").

36 See Katherine Barrett \& Carolyn Raffensperger, Precautionary Science, in ImPLEmEnTING The Precautionary Principle, supra note 21, at 106, 117; Nicholas A. Ashford, A Conceptual Framework for the Use of the Precautionary Principle in Law, in IMPLEMENTING THE PRECAUTIONARY PRINCIPLE, supra note 21, at 198, 202-03.

37 This chart is adapted from SCIENCE AND THE ESA, supra note 12, at 166 tbl.8-1. 


\begin{tabular}{|l|l|l|}
\hline Error Type & Type I & Type II \\
\hline Hypothesis Error & Reject true null hypothesis & Accept false null hypothesis \\
\hline Conclusion Error & Claim effect when none exists & $\begin{array}{l}\text { Claim no effect when one } \\
\text { exists }\end{array}$ \\
\hline $\begin{array}{l}\text { Species } \\
\text { Consequences }\end{array}$ & Protected more than necessary & $\begin{array}{l}\text { Protected less than } \\
\text { necessary, possibly leading } \\
\text { to extinction }\end{array}$ \\
\hline $\begin{array}{l}\text { Socioeconomic } \\
\text { Consequences }\end{array}$ & $\begin{array}{l}\text { Increase socioeconomic costs } \\
\text { more than necessary }\end{array}$ & $\begin{array}{l}\text { Permit activities that should } \\
\text { not have been approved }\end{array}$ \\
\hline
\end{tabular}

Again, neither the Scientific Method in its aversion to Type I error, nor the Precautionary Principle Method in its aversion to Type II error, is normative in motivation. Rather, it is when they are placed in the highly normative context of regulatory programs such as the ESA that the fighting begins over which is more appropriate. Using the previously described example, if Congress instructs an agency that it may regulate a chemical only if it finds that unrestricted use will cause significant harm, one can predict how different interest groups will use the three frameworks. Those interested in seeing the chemical remain unregulated will argue that the agency must test the decision hypothesis Congress has mandatedunrestricted use will cause significant harm-using the Scientific Method. They will appeal to Type I risk aversion and demand high levels of certainty before the agency takes regulatory action. By contrast, persons hoping that the chemical will be regulated would urge the agency to adopt the Precautionary Principle Method, appealing to the dire environmental consequences of Type II error and arguing for relaxed evidentiary standards before the agency can move to regulate the chemical. Thus, without changing the substance of the agency's statutory directive, choice of methodology can change the substantive outcome of the agency's decisions.

\section{ESA DECISION NODES}

As the preceding section demonstrates, in order to understand the effect of using different methodologies to implement the ESA, and why the fight over which to use is intensifying, one first has to appreciate how Congress has structured the decision hypotheses the agencies must use. ${ }^{38}$ FWS and NMFS administer several core programs, of which some of the details are more fully explored later in the Article:

- Section 4 authorizes FWS and NMFS to identify "endangered" and "threatened" species, known as the "listing" function, ${ }^{39}$ and then to

38 I have had the pleasure of being asked to make presentations and write commentary for publication about the ESA many times. Out of necessity, the materials in this "background" section of this Article are a variation, tailored for the instant purposes, of a template I have developed and used to inform readers not familiar with the ESA of the statute's basic structure. Similar treatments, in other words, appear elsewhere in my published works.

3916 U.S.C. $\$ 1533(\mathrm{a})(1)$ (2000). For a description of the listing process, see SELS, supra note 1, at 38-58; LIEBESMAN \& PETERSEN, supra note 1, at 15-20; SUlLINS, supra note 1, at 11-25; 
designate "critical habitat" 40 and develop "recovery plans" for the species. ${ }^{41}$

- Section 7 requires all federal agencies to ensure that actions they carry out, fund, or authorize do not "jeopardize" the continued existence of listed species or "adversely modify" their critical habitat. ${ }^{42}$

- $\quad$ Section 9 requires that all persons, including all private and public entities subject to federal jurisdiction, avoid committing "take" of listed species of fish and wildlife. ${ }^{43}$

- Sections 7 (for federal actions) and 10 (for actions not subject to Section 7) establish a procedure and criteria for FWS and NMFS to approve "incidental take" of listed species. ${ }^{44}$

A reader unfamiliar with the ESA may find this structure quite simple and expect its application to be quite straightforward. Indeed, by comparison to other federal environmental laws, the ESA is streamlined,

J.B. Ruhl, Section 4 of the ESA: The Keystone of Species Protection Law, in LAw, PoLICY, AND PERSPECTIVES, supra note 1, at 19.

4016 U.S.C. $\S 1533$ (a)(3) (2000). For a description of the critical habitat designation process, see SELS, supra note 1, at 59-69; LIEBESMAN \& PETERSEN, supra note 1, at 20-24; SULLINS, supra note 1, at 26-28; Federico Cheever, Endangered Species Act: Critical Habitat, in LaW, PoLICY, AND PERSPECTIVES, supra note 1, at 47; Murray D. Feldman \& Michael J. Brennan, The Growing Importance of Critical Habitat for Species Conservation, 16 NAT. RESOURCES \& ENV'T 88 (2001). FWS has an unmistakable policy aversion to designating critical habitat, arguing on many occasions that it "provides little or no conservation benefit despite the great cost to put it in place." Endangered and Threatened Wildlife and Plants; Final Determination of Critical Habitat for the Southwestern Willow Flycatcher, 62 Fed. Reg. 39,129, 31,130 (July 22, 1997). In addition, because few people understand its implications, FWS believes that the critical habitat process "can arouse concern and resentment on the part of private landowners and other interested parties." Endangered and Threatened Wildlife and Plants; Proposed Rule to List Three Aquatic Snails as Endangered, and Three Aquatic Snails as Threatened in the Mobile River Basin of Alabama, 62 Fed. Reg. 54,020, 54,024 (Oct. 17, 1997).

4116 U.S.C. $\S 1533(\mathrm{f})$ (2000). For a description of the recovery plan process, see SELS, supra note 1, at 71-77; LIEBESMAN \& PETERSEN, supra note 1, at 24-26; SULLINS, supra note 1, at 34-38; John M. Volkman, Recovery Planning, in LAW, POLICY, AND PERSPECTIVES, supra note 1, at 71.

4216 U.S.C. $\$ 1536$ (a)(2) (2000). For a description of the consultation process, see SELS, supra note 1, at 83-103; LIEBESMAN \& PETERSEN, supra note 1, at 27-39; SULLINS, supra note 1, at 59-86; Marilyn Averill, Protecting Species Through Interagency Cooperation, in LAW, POLICY, AND PERSPECTIVES, supra note 1 , at 87.

4316 U.S.C. $\& 1538$ (a)(1) (2000). For a description of the cases developing the legal standards for what constitutes "take," see SELS, supra note 1, at 104-12; LIEBESMAN \& PETERSEN, supra note 1, at 39-45; SUlLins, supra note 1, at 44-53; Gina Guy, Take Prohibitions and Section 9, in LAW, Policy, AND PERSPectives, supra note 1, at 191; Steven P. Quarles \& Thomas R. Lundquist, When Do Land Use Activities "Take" Listed Wildlife Under ESA Section 9 and the "Harm" Regulation?, in LAW, POLICY, AND PERSPECTIVES, supra note 1, at 207; Alan M. Glen \& Craig M. Douglas, Taking Species: Difficult Questions of Proximity and Degree, 16 NAT. RESOURCES \& ENV'T 65 (2001).

4416 U.S.C. $\$ \S 1536(\mathrm{~b})(4), 1539$ (a)(1) (2000). "Incidental take," although not the subject of a specific statutory definition provision, is described elsewhere in the statute as a take that is "incidental to, and not the purpose of, the carrying out of an otherwise lawful activity." Id. § 1539(a)(1)(B). The FWS and NMFS have adopted this meaning for purposes of the regulations implementing section 7. 50 C.F.R. $\$ 402.02$ (2004). For a description of the incidental take authorization procedures, see SELS, supra note 1, at 127-73; LIEBESMAN \& PETERSEN, supra note 1 , at $46-50$; SulLins, supra note 1 , at 87-102. 
almost miniscule. ${ }^{45}$ The core programs seem to fit together neatly: Identify problem species and their essential habitat areas; stop public and private actions from further significantly deteriorating their condition; allow actions that kill or injure species members only under strict permitting guidelines; figure out ways to help them recover to sustainable populations. This is a fitting game plan for providing "a means whereby the ecosystems upon which endangered species and threatened species depend may be conserved" 46 and "to halt and reverse the trend toward species extinction, whatever the cost. ${ }^{n 47}$

As is often the case with seemingly uncomplicated statutes, however, the devil is in the details. Each of the administrative programs outlined above involves an intersection between legal standards and a multitude of scientific determinations. The problem is not one simply of uncertainty for lack of data, though that is surely a driver in the difficulties of ESA administration. Rather, the fit between the two domains is often not tight even when the available data are robust by scientific standards. The legal standards call for determinations that scientists usually are reluctant to make, and the information and analyses science produces often lead to inconclusive outcomes under the legal standards. Consider the following inventory of some of the coupled law-science decisions the ESA requires FWS and NMFS to make:

\begin{tabular}{|l|l|l|}
\hline Program & Legal Standard & Science Questions \\
\hline $\begin{array}{l}\text { Section } 4 \\
\text { Listing }\end{array}$ & $\begin{array}{l}\text { Is the species in danger of } \\
\text { extinction throughout all } \\
\text { or a significant portion of } \\
\text { its range (endangered) or } \\
\text { likely to become so in the } \\
\text { foreseeable future } \\
\text { threatened) }^{48}\end{array}$ & $\begin{array}{l}\text { Is it a species } ?^{49} \text { What is its range? } \\
\text { What are the present and threatened } \\
\text { injuries to its habitat }{ }^{50} \text { Is it being } \\
\text { over-utilized for commercial or other } \\
\text { purposes? Is it threatened by disease } \\
\text { or predation? Overall, are these } \\
\text { threats enough to cause it to go } \\
\text { extinct? When? What is the } \\
\text { probability? }\end{array}$ \\
\hline
\end{tabular}

45 In one unannotated collection of environmental statutes, the ESA took up 34 pages compared to 177 pages for the Clean Water Act and 306 pages for the Clean Air Act. See ROBERT V. PERCiVAL, ENVIRONMENTAL LAW: STATUTORY SUPPLEMENT AND INTERNET GUIDE (2002).

4616 U.S.C. $\$ 1531$ (b) (2000).

47 Tenn. Valley Auth. v. Hill, 437 U.S. 153, 184 (1978).

48 These are the definitions of endangered species and threatened species. 16 U.S.C. $\$ 1532(6),(20)(2000)$.

49 For a discussion of this seemingly straightforward question, see infra notes $65-68$ and accompanying text.

50 This and the remaining questions posed for the listing function are taken from the statutory criteria. 16 U.S.C. $\$ 1533(\mathrm{a})(1)(\mathrm{A})-(\mathrm{E})$ (2000). 


\begin{tabular}{|c|c|c|}
\hline Program & Legal Standard & Science Questions \\
\hline $\begin{array}{l}\text { Section } 4 \\
\text { Critical } \\
\text { Habitat } \\
\text { Designation }\end{array}$ & $\begin{array}{l}\text { What habitat is essential } \\
\text { to the conservation of the } \\
\text { species and requires } \\
\text { special management } \\
\text { considerations? }\end{array}$ & $\begin{array}{l}\text { How much space does the species } \\
\text { need for individual and population } \\
\text { growth }{ }^{52} \text { What are its food, water, } \\
\text { air, light, mineral, shelter, and other } \\
\text { nutritional and physiological } \\
\text { requirements? Where does it breed, } \\
\text { reproduce, and rear offspring? What } \\
\text { are the constitutive elements of } \\
\text { habitat serving these functions and } \\
\text { needs? Where is such habitat? How } \\
\text { much of it does the species require? }\end{array}$ \\
\hline $\begin{array}{l}\text { Section } 4 \\
\text { Recovery } \\
\text { Planning }\end{array}$ & $\begin{array}{l}\text { What measures are } \\
\text { necessary to bring the } \\
\text { species to the point at } \\
\text { which it is no longer } \\
\text { endangered or threatened, } \\
\text { and by what objective, } \\
\text { measurable criteria can } \\
\text { that determination be } \\
\text { made? }\end{array}$ & $\begin{array}{l}\text { What site-specific and general } \\
\text { management actions can reduce the } \\
\text { threats that caused the species to be } \\
\text { listed }{ }^{54} \text { How will we measure the } \\
\text { magnitude of those benefits? When } \\
\text { will the benefits have reached the } \\
\text { point that we can justify removing } \\
\text { the species from the lists? }\end{array}$ \\
\hline $\begin{array}{l}\text { Section } 7 \\
\text { Jeopardy } \\
\text { Prohibitions }\end{array}$ & $\begin{array}{l}\text { Will the direct and indirect } \\
\text { effects of the federal } \\
\text { action jeopardize the } \\
\text { continued existence of the } \\
\text { species }^{55} \text { by appreciably } \\
\text { reducing its chances of } \\
\text { recovery and survival in } \\
\text { the wild? }\end{array}$ & $\begin{array}{l}\text { What are the impacts of the action } \\
\text { on reproduction, numbers, or } \\
\text { distribution of the species? }{ }^{57} \text { How } \\
\text { much do such impacts reduce the } \\
\text { species' chances of surviving and } \\
\text { recovering in the wild? }\end{array}$ \\
\hline
\end{tabular}

51 This is taken from the definition of critical habitat. Id. $\$ 1532(5)$.

52 This and the other critical habitat designation questions are summarized in the agency regulations. 50 C.F.R. $\$ 424.12$ (b)(1)-(5) (2004).

53 This is taken from the definition of "conservation," which is what recovery plans are supposed to accomplish. See 16 U.S.C. $\S 1532(3)$ (2000) (defining conservation); id. $\S 1533(\mathrm{f})$ (recovery plans are for conservation of species).

54 These questions are from the statutory procedure for recovery plan development. See id. $\S 1533(\mathrm{f})(1)(\mathrm{B})$ (setting forth elements of recovery plan).

55 This is the statutory prohibition of jeopardy. Id. $\S 1536(\mathrm{a})(2)$ (requiring agencies to ensure no agency action jeopardizes a listed species).

56 The agency regulations elaborate on the statute with this definition of "jeopardize." See 50 C.F.R. $\$ 402.02$ (2003) (defining jeopardy).

57 These are the criteria set forth in the regulatory definition. Id. 


\begin{tabular}{|c|c|c|}
\hline Program & Legal Standard & Science Questions \\
\hline $\begin{array}{l}\text { Section } 7 \\
\text { Adverse } \\
\text { Modification } \\
\text { Prohibition }\end{array}$ & $\begin{array}{l}\text { Will the direct and indirect } \\
\text { effects of the federal } \\
\text { action result in the } \\
\text { destruction or adverse } \\
\text { modification of critical } \\
\text { habitat of the species }{ }^{58} \text { by } \\
\text { appreciably diminishing } \\
\text { the value of the habitat for } \\
\text { the survival and recovery } \\
\text { of the species? }\end{array}$ & $\begin{array}{l}\text { How does the action alter any of the } \\
\text { physical and biological features that } \\
\text { were the basis for determining the } \\
\text { habitat to be critical }{ }^{60} \text { How much } \\
\text { do such impacts reduce the species' } \\
\text { chances of surviving and recovering } \\
\text { in the wild? }\end{array}$ \\
\hline $\begin{array}{l}\text { Section } 9 \\
\text { Take } \\
\text { Prohibition }\end{array}$ & $\begin{array}{l}\text { Will a person's action } \\
\text { harass, harm, shoot, } \\
\text { pursue, hunt, wound, kill, } \\
\text { trap, capture, or collect } \\
\text { any individuals of the } \\
\text { species? }^{61}\end{array}$ & $\begin{array}{l}\text { Does the action actually kill or injure } \\
\text { wildlife? For the "harm" } \\
\text { determination, does the action } \\
\text { modify or degrade habitat so as to } \\
\text { impair behavioral patterns such as } \\
\text { breeding, feeding, or sheltering, and } \\
\text { if so, has that killed or injured } \\
\text { individuals of the species? }\end{array}$ \\
\hline $\begin{array}{l}\text { Section } 7 \\
\text { Incidental } \\
\text { Take } \\
\text { Permitting }\end{array}$ & $\begin{array}{l}\text { What reasonable and } \\
\text { prudent measures are } \\
\text { necessary or appropriate } \\
\text { to minimize the impact of } \\
\text { the incidental taking? }\end{array}$ & $\begin{array}{l}\text { What is the nature and magnitude of } \\
\text { the take being authorized, and by } \\
\text { what measures and magnitude has } \\
\text { the agency minimized such take? }\end{array}$ \\
\hline $\begin{array}{l}\text { Section } 10 \\
\text { Incidental } \\
\text { Take } \\
\text { Permitting }\end{array}$ & $\begin{array}{l}\text { Has the applicant } \\
\text { minimized and mitigated } \\
\text { the impacts of the } \\
\text { incidental taking to the } \\
\text { maximum extent } \\
\text { practicable and not } \\
\text { appreciably reduced the } \\
\text { likelihood of the survival } \\
\text { and recovery of the } \\
\text { species? }\end{array}$ & $\begin{array}{l}\text { What is the nature and magnitude of } \\
\text { the take being authorized, and by } \\
\text { what measures and magnitude has } \\
\text { the applicant minimized and } \\
\text { mitigated such take? What is the net } \\
\text { effect of the take, as minimized and } \\
\text { mitigated, on the ability of the } \\
\text { species to survive and recover? }\end{array}$ \\
\hline
\end{tabular}

58 This is the statutory prohibition of adverse modification. 16 U.S.C. $\$ 1536(a)(2)$ (2000).

59 The agency regulations elaborate on the statute with this definition of "adverse modification." 50 C.F.R. $\$ 402.02$ (2004).

60 These are the criteria set forth in the regulatory definition. Id.

61 This is the statutory definition of take. 16 U.S.C. $\$ 1532(19)$ (2000).

62 This is the regulatory definition of harm. 50 C.F.R. $\$ 17.3$ (2004). For a recent summary of the history of this administrative interpretation of "harm" and the case law construing it, see Steven G. Davison, The Aftermath of Sweet Home Chapter: Modification of Wildlife Habitat as a Prohibited Taking in Violation of the Endangered Species Act, 27 WM. \& MARY ENVTL. L. \& POL'Y REv. 541 (2003).

63 This is the statutory standard for issuance of a section 7 incidental take statement. 16 U.S.C. $\$ 1536(b)(4)(2000)$.

64 These are the statutory criteria for issuance of a section 10 incidental take permit. Id. $\S$ $1539(\mathrm{a})(2)$. 
This illustration presents only the tip of the iceberg. Any one of the science questions could be unpacked to reveal a wealth of additional inquiries that press even harder on the question of methodology. For example, the very first and seemingly most basic question posed-whether we are dealing with a species-opens the door to debate over methodology. There is often sparse or inconclusive data available to allow a scientist to make a definitive determination of species definition. How certain do we wish to be that an organism represents a distinct species before we make the protections of the ESA available to it? Even where we agree on that question, the legal definition of species strikes many scientists as nonsensical. ${ }^{65}$ The ESA defines species to include "any subspecies of fish or wildlife or plants, and any distinct population segment of any species of vertebrate fish or wildlife which interbreeds when mature. ${ }^{" 66}$ Scientists have enough trouble defining a species; now they must also define subspecies and distinct population segments, matters sure to engender yet more methodological debate. ${ }^{67}$ Expand these questions beyond the halls of science to the policy context of ESA implementation, and the combative array of ESA interest groups will unleash the methodology debate into the courts, the agencies, and Congress at every available turn. They have fought tooth-and-nail over the species question alone. ${ }^{68}$ Multiply that by the countless other questions the ESA makes FWS and NMFS decide, and one quickly can appreciate why methodology matters under the ESA.

\section{THREe COMPETING MOdels OF ESA METHOdOLOGY}

Clearly, the choice between methodologies will influence substantive outcomes under the ESA. What makes methodology selection so

65 For a comprehensive comparison of the biological and legal conceptions of "species," see Blake Hood, Transgenic Salmon and the Definition of "Species" Under the Endangered Species Act, 18 J. LAND USE \& ENVTL. L. 75, 78-98 (2002). As two close observers of the ESA have put it, "the ESA requires scientists to provide clear answers to fuzzy questions that many scientists do not define as 'scientific,' such as whether a species is endangered or whether a specific project is likely to cause jeopardy." Holly Doremus \& A. Dan Tarlock, Fish, Farms, and the Clash of Cultures in the Klamath Basin, 30 Ecology L.Q. 279, 325 (2003).

66 See 16 U.S.C. $\$ 1532(16)$ (2000) (defining species).

67 "The scientific consensus on 'species' ... is that no complete consensus exists and that different definitions suit different purposes." Hood, supra note 65, at 78. The default position in science as to what constitutes a species relies on Ernst Mayr's "biological species concept," which focuses on reproductive isolation. Id. at 81-82. Still, actually defining the boundaries of a species, and deciding whether a particular organism belongs to one or another, involves complex observational, morphological, and genetic considerations. Id. at 82-83. The concept of "subspecies" has not played an important role in science. Id. at 83. The concept of a "population," by contrast, is generally accepted in science as an essential unit of genetic evolution. Id. at 83-84. For additional discussion of the debate surrounding how to define a species, both legally and scientifically, see SELS, supra note 1, at 31-38; LIEBESMAN \& PETERSEN, supra note 1, at 11-15; SulLINS, supra note 1, at 6-11; Doremus, supra note 15, at 1087-1112.

68 Several cases turn on whether FWS or NMFS has correctly defined what constitutes a species within the meaning of the statute. See LIEBESMAN \& PETERSEN, supra note 1, at 11-15 (providing comprehensive discussion about definition of species). 
controversial under the statute, however, is that the three frameworks for methodology selection present no clear winner.

The statute suggests at numerous junctures that the agencies should seek to instill a high level of certainty in their decisions. For example, the process for conducting inter-agency consultation under section 7 involves exchange of detailed scientific reports between the agencies. ${ }^{69}$ But the statute subjects this process and many other required actions to strict deadlines, suggesting that certainty has its limits and a decision must be reached. ${ }^{70}$ Presumably, Congress wants the agencies to be as sure as they can be about their decisions, within the given time frames.

The action hypotheses prescribed under the ESA are also a mixed bag. For example, FWS and NMFS must prove a cause-and-effect relationshipthat an action is the proximate cause of death or injury to individuals of a listed species-if they wish to enforce the section 9 take prohibition. ${ }^{71}$ But they must find the absence of a cause-and-effect relationship-that an action will not appreciably reduce the likelihood of a species' survival-in order to issue an incidental take permit under Section $10{ }^{72}$ Most of the action hypotheses lean in the direction of requiring FWS and NMFS to find some adverse condition to the species before regulating, rather than to regulate unless it finds no adverse condition, but in few cases is the wording of the statute strong in either direction.

Similarly, either way an action hypothesis is stated, both types of decision error are quite costly under the ESA. Known as one of the most powerful of environmental laws, the consequences of mistaken overprotection of species can be costly in socioeconomic terms. ${ }^{73}$ But the purpose of the statute is to avoid the extinction of species, and mistaken denial of protection could have the ultimate in irreversible consequences for an imperiled species. Ideally, we would like to avoid both of these consequences of mistaken agency decisions.

If the agencies could be right all the time, we would have no need to decide how certain we need to be, or how to state action hypotheses for the agencies, or to ask which type of error we wish to avoid more, but we know

69 See 16 U.S.C. $\$ 1536$ (b)-(c) (2000) (describing procedures regarding consultation and biological assessment).

70 See, e.g., id. \$1536(b)(1)(a), (c)(1).

71 This is the interpretation widely given to the Supreme Court's exposition on the harm definition in Babbitt v. Sweet Home Chapter of Communities for a Great Oregon (Sweet Home), 515 U.S. 687 (1995), and the case law Sweet Home spawned. See SELS, supra note 1, at 109-12 (discussing the Sweet Home definition of harm's inclusion of indirect harm and the Ninth Circuit's broad definition of harm); LIEBESMAN \& PETERSEN, supra note 1, at 40-44; SulLinS, supra note 1, at 46-53 (same, plus discussion of the First Circuit and Massachusetts and Florida district court interpretations); Quarles \& Lundquist, supra note 43, at 211-39; Glen \& Douglas, supra note 43, at 66-69. For an especially thorough treatment of this topic, likening the Sweet Home standard to that of a tort claim, see James R. Rasband, Priority, Probability, and Proximate Cause: Lessons from Tort Law About Imposing ESA Responsibility for Wildlife Harm on Water Users and Other Joint Habitat Modifiers, 33 ENVTL. L. 595 (2003).

7216 U.S.C. $\$ 1539$ (a)(2)(B)(iv) (2000).

73 For example, see the discussion below of the Klamath River Basin, infra notes 119-20 and accompanying text. 
that will not be the case. FWS and NMFS will be wrong sooner or later regardless of which methodology we chose. The battle over ESA methodology thus ensues.

\title{
A. The Professional Judgment Method-Working With the "Best Scientific Data Available"
}

The Professional Judgment Method is well known to administrative law practitioners of all walks. Based on the premise of agencies as repositories of professional expertise, legislation delegating authority to the agency specifies the array of substantive decision nodes to which methodological constraints may be attached, such as whether cost-benefit analysis must or must not be considered in the decision analysis. From there, however, the default position is usually one of allowing the agency to exercise professional judgment. Using this approach, agencies exercise their expertise to make their decisions and, if any disgruntled party with standing challenges the decision, rules of judicial review step into play.

The conventional rules of judicial review - the default rules when the agency's organic act is silent-are found in the Administrative Procedure Act (APA). ${ }^{74}$ These rules require the courts to apply considerable deference to the agency's decision. A reviewing court may not substitute its judgment for the agency's, but must undertake a "thorough, probing, in-depth review" of the agency's decision. ${ }^{75}$ Thus, a court will reject an agency's decision if it is "arbitrary, capricious, an abuse of discretion, or otherwise not in accordance with law." ${ }^{76}$ An agency decision is arbitrary and capricious if the agency either

\begin{abstract}
has relied on factors which Congress had not intended it to consider, entirely failed to consider an important aspect of the problem, offered an explanation for its decision that runs counter to the evidence before the agency, or is so implausible that it could not be ascribed to a difference in view or the product of agency expertise, ${ }^{77}$
\end{abstract}

or if it has failed to "articulate a satisfactory explanation for its action including a rational connection between the facts found and the choice made." 78 Put simply, the agency has failed to exercise properly its professional judgment as defined above. The ESA has been widely

745 U.S.C. $\$ 706(2000)$.

75 Citizens to Pres. Overton Park, Inc. v. Volpe, 401 U.S. 402, 415 (1971).

765 U.S.C. $\$ 706(2)$ (A) (2000); Biodiversity Legal Found. v. Babbitt, 146 F.3d 1249, 1252 (10th Cir. 1998).

77 State Farm, 463 U.S. 29, 43 (1983).

$78 \mathrm{Id}$. (internal quotation omitted). 
interpreted as being subject to these rules with no substantial exceptions. ${ }^{79}$ The ESA is, in other words, a Professional Judgment Method statute. ${ }^{80}$

Under this framework, agency decision making is controlled by one dominant theme: how not to be arbitrary, capricious, in abuse of discretion, or out of accordance with law in the flexing of professional judgment. The fewer methodological constraints a statute places on an agency, the less opportunity a court has to measure the agency's use of professional judgment against anything other than a test for behavior that is obviously the result of blind ambition or sheer arrogance. Where methodological constraints are imposed, moreover, the agency's task is simply to demonstrate that the agency acted within the constraints in a way that traces a rational connection between the decision and the record of evidence. Thus, if cost-benefit analysis is not allowed, then the agency must show its decision does not rest explicitly on cost-benefit analysis. Agencies acculturated to this approach, therefore, learn how to dot their i's and cross their t's to meet the deferential standards of judicial review. Overall, while agencies occasionally violate these rules, the Professional Judgment Method is not a particularly demanding system.

The ESA contains plenty of substantive decision nodes to which these rules apply; yet, given its purpose of preventing the extinction of species, the ESA is remarkably devoid of meaningful decision-making method constraints with which the courts are to evaluate agency decisions. As an intersection between biological science and law, the reliability of decision making under the ESA necessarily depends on the quantity and quality of scientific information available to and used by the decision makers. The ESA could hardly operate on less than robust and reliable scientific data. But what is the agency supposed to do about defining, obtaining, and evaluating that universe of data in order to make its substantive decisions? What is its decision-making method to be?The most prominent response found in the ESA is the so-called "best scientific data available" standard, which permeates several of the statute's major decision nodes. For example, when deciding whether to list a species, FWS and NMFS must consider factors

79 See, e.g., Maine v. Norton, 257 F. Supp. 2d 357, 389 (D. Maine 2003) ("Even where there are competing expert opinions, or where the scientific data are equivocal, it is the agency's prerogative 'to weigh those opinions and make a policy judgment based on the scientific data."') (quoting Brower v. Daley, 93 F. Supp. 2d 1071, 1082-83 (N.D. Cal. 2000)); Am. Wildlands v. Norton, 193 F. Supp. 2d 244, 257 (D.D.C. 2002) (determining that FWS's decision not to list the westslope cutthroat trout (Oncorhyncus clarki lewisi) did not reflect a reasonable assessment, and thus violated APA); Loggerhead Turtle v. County Council of Volusia County, 120 F. Supp. 2d 1005, 1026 (M.D. Fla. 2000) (finding FWS's issuance of an incidental take permit based on enough support to withstand APA challenge); Friends of the Wild Swan, Inc. v. United States Fish \& Wildlife Serv., 945 F. Supp. 1388, 1401 (D. Or. 1996) (holding FWS's decision to deny emergency listing to bull trout (Salvelinus confluentus) arbitrary and capricious because it did not adequately explain denial); see generally Michael J. Brennan et al., Square Pegs and Round Holes: Application of the "Best Scientific Data Available" Standard in the Endangered Species Act, 16 TUL. ENVTL. L.J. 387, 409-12 (2003).

80 See, e.g., Loggerhead Turtle, 120 F. Supp. 2d at 1023 ("Where there is a substantial volume of research, data, and comments, the agency exercises its expertise to make a reasonable decision based on all of the data and information."). 
such as loss of habitat ${ }^{81}$ using only "the best scientific and commercial data available." ${ }^{82}$ Similarly, the biological component of the decision whether to designate critical habitat must use the "best scientific data available." ${ }^{83}$ And the "no jeopardy" and "no adverse modification" directives to federal agencies, which rely on a consultation procedure between the action agency and ESA agency with jurisdiction over the species in question, ${ }^{84}$ adopt the same standard. ${ }^{85}$

Although the ESA leaves this "best scientific data available" standard of evidentiary quality undefined, ${ }^{86}$ its "obvious purpose . . . is to ensure that the ESA not be implemented haphazardly, on the basis of speculation or surmise." ${ }^{87}$ It is, in other words, a check on both the hasty application of precaution and the uninformed use of science. Accordingly, the courts have interpreted it to impose several practical guidelines on the agencies: ${ }^{88}$

- The agencies may not manipulate their decisions by "unreasonably relying on certain sources to the exclusion of others." 89

- The agencies may not disregard "scientifically superior evidence."90

- Relatively minor flaws in scientific data do not render that information unreliable. ${ }^{91}$

- The agencies must use the best data available, not the best data possible. $^{92}$

- The agencies may not insist on conclusive data in order to make a decision. ${ }^{93}$

- The agencies are not required to conduct independent research to improve the pool of available data. ${ }^{94}$

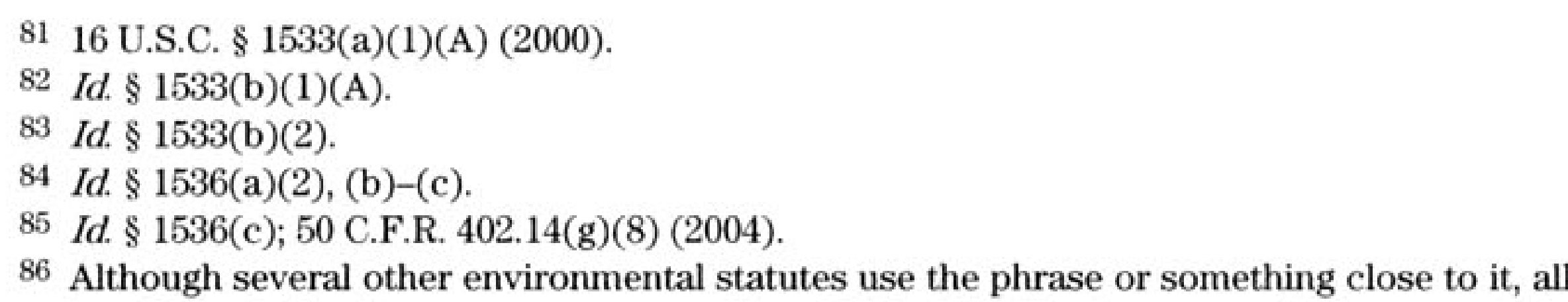
leave it undefined. See Doremus, supra note 15, at 1034 n.9 (collecting statutes); Brennan et al., supra note 79 , at $402 \mathrm{n} .81$ (collecting statutes).

87 Bennett v. Spear, 520 U.S. 154, 176 (1997).

88 See Southwest Ctr. for Biological Diversity v. Norton, 2002 WL 1733618, at *8 (D.D.C. 2002) (summarizing the existing body of case law). For further discussion of these guidelines see generally Brennan et al., supra note 79, at 396-430; Doremus, supra note 15, at 1051-85; John Earl Duke, Giving Species the Benefit of the Doubt, 83 B.U. L. REv. 209 (2003); Laurence Michael Bogert, That's My Story and I'm Sticking To It: Is the "Best Available" Science Any Available Science Under the Endangered Species Act?, 31 IDAHO L. REv. 85 (1994).

89 Southwest Ctr. for Biological Diversity, 2002 WL 1733618 at *8.

90 Id. (quoting Las Vegas v. Lujan, 891 F.2d 927, 933 (D.C. Cir. 1989), and citing Southwest Ctr. for Biological Diversity v. Babbitt, 926 F. Supp. 920, 927 (D. Ariz. 1996)).

91 Id. (citing Bldg. Indus. Ass'n of Superior Cal. v. Norton, 247 F.3d 1241, 1246-47 (D.C. Cir. 2001)).

92 Id. (citing Bldg. Indus. Ass'n of Superior Cal., 247 F.3d at 1246).

93 Id. at *9 (citing Defenders of Wildlife v. Babbitt, 958 F. Supp. 670, 680 (D.D.C. 1997)).

94 Id. 
- The agencies thus "must rely on even inconclusive or uncertain information if that is the best available at the time" of the decision. ${ }^{95}$

- The agencies must manage and consider the data in a transparent administrative process. ${ }^{96}$

Similarly, in 1994 FWS and NMFS issued a joint policy providing guidelines for how the agencies will ensure their ESA decisions incorporate this evidentiary standard ${ }^{97}$ Where the agencies make ESA implementation decisions, including species listing, jeopardy consultations, and incidental take authorizations, the policy directs the agencies to follow six guidelines:

- Require that all biologists "evaluate all scientific and other information that will be used" to make the decision. ${ }^{98}$

- "Gather and impartially evaluate biological, ecological, and other information that disputes official positions, decisions, and actions proposed or taken" by FWS or NMFS. ${ }^{99}$

- Ensure that biologists document their "evaluation of information that supports or does not support a position being proposed" by the agency. ${ }^{100}$

- "Use primary and original sources of information as the basis" for consultation decisions or recommendations. ${ }^{101}$

- Adhere to the timeframes or "schedules" established by the ESA. ${ }^{102}$

- "Conduct management-level review of documents developed ... [by the agency] ... to verify and assure the quality of the science used to established official positions." 103

All that sounds impressive, but the question arises whether appending "best," "scientific," and "available" to the general standard that agencies base their decisions on evidence in the record has made any appreciable difference in the outcome of ESA decisions. ${ }^{104}$ Most other environmental laws do not contain the same or any similar condition on the quality of the evidence that an agency may consider, but there is no evidence that the agencies implementing those laws routinely base decisions on evidence that is poor, nonscientific, or unavailable, particularly when better, more scientific evidence is available. If they did, the default rules for those statutes are provided in the conventional judicial review provisions of the

\footnotetext{
95 Id.

96 For a discussion of some of the case law that imposes this requirement, see Doremus, supra note 15 , at $1084-87$.

97 Endangered and Threatened Wildlife and Plants: Notice of Interagency Cooperative Policy on Information Standards Under the Endangered Species Act, 59 Fed. Reg. 34,271 (July 1, 1994).

98 Id. at 34,271 .

99 Id.

100 Id.

101 Id.

102 Id.

103 Id.

104 I have also examined this question in connection with work exploring the pragmatic qualities of the ESA. See J.B. Ruhl, Is the Endangered Species Act Ecopragmatic?, 87 MrNN. L. REV. 885, 927-29 (2003).
} 
APA, under which any court would routinely find that an agency's reliance on sloppy, filtered, or haphazard evidence is arbitrary and capricious. ${ }^{105}$ So, why not just leave it at that for the ESA? What do "best," "scientific," and "available" add?

Indeed, it is difficult to pinpoint the incremental legal effect, if any, of the "best scientific data available" standard. On the one hand, the courts behave as if the standard means something, ${ }^{106}$ yet it is not clear that any of the decisions finding the standard to have been satisfied or violated would have turned out differently under the conventional APA judicial review tests. It is not possible to extract from case law, administrative policy, or legislative intent any independent mandate of agency decision-making method or standard of judicial review the provision adds to the picture. Nor does commentary on the standard suggest that it imposes higher duties. ${ }^{107}$ Consider the list presented above describing the gloss the courts have put on the "best scientific data available" standard. None of the guidelines would be foreign to other agencies implementing other environmental laws. None of the guidelines offends or expands upon the standards of conventional judicial review. Indeed, the guidelines explicitly prevent FWS or NMFS from declining to act on the basis that with more time more data could be obtained. In short, "best available scientific evidence" sounds powerful, but, as interpreted and implemented, it has probably not led to outcomes any different from those that would have been permitted or rejected under the Professional Judgment Method.

Having demonstrated that the standard does not mandate something more demanding than the Professional Judgment Method, it is equally true that it does not explicitly permit or mandate anything lower on the decision grounds hierarchy either. A decision that does not rest comfortably in the body of the best scientific data available-that does not follow the guidelines the courts have applied under that standard-must find some independent permissible justification or be struck down. In other words, acting cautiously or intuitively, but in conflict with the best scientific data available, is risky agency behavior under the ESA. ${ }^{108}$ Hence, the ESA, insofar as its most important decision nodes are concerned, is methodologically neither "scientific" nor "precautionary." Indeed, at their core, the two opposing themes of methodological reform reflect frustration with the

105 5 U.S.C. $\$ 706$ (2000).

106 See, e.g., Southwest Ctr. for Biological Diversity v. Norton, No. 98-934 (RMU/JMF) 2002 WL 1733618, at *8-9 (D.D.C. 2002) (noting that courts have interpreted "best scientific data" to mean, among other things, improperly using certain data to the exclusion of other data, disregarding "scientifically superior evidence," and ignoring uncertain data even if it is the best available).

107 See, e.g., LIEBESMAN AND PETERSEN, supra note 1, at 16 (discussing the standard in the context of the basic APA judicial review criteria); Brennan et al., supra note 79, at 412-32 (presenting a thorough review of cases interpreting the "best scientific data available" standard). For a particularly probing analysis of this issue and of the current law and policy of the "best available scientific evidence" mandate in general, see Holly Doremus, The Purposes, Effects, and Future of the Endangered Species Act's Best Available Science Mandate, 34 ENVTL. L. 397 (2004).

108 For examples, see infra notes 172, 187-97 and accompanying text. 
apparent indifference the Professional Judgment Method shows to science and precaution.

Yet it is not as if the ambivalence of the Professional Judgment Method makes it empty of structured methodology. The agencies cannot be cavalier in their exercise of discretion, acting as a black box of decision making without revealing their methods. They have often been criticized for doing just that, ${ }^{109}$ and increasingly courts are demanding that the agencies reveal their methods for reaching decisions, and that those methods be meaningful in scope. Recently, for example, the court in Home Builders Ass'n of Northern California v. United States Fish \& Wildlife Service ${ }^{110}$ accepted the premise that FWS operates under the Professional Judgment Method, ${ }^{111}$ but explained that this carries with it several methodological standards FWS must satisfy in order to fulfill properly its substantive critical habitat designation duties: ${ }^{112}$

- The Service must describe a method for determining how and when the species can be considered conserved, so that it can determine whether a particular physical or biological element is essential to the conservation of the species. ${ }^{113}$

- The Service must provide a particularized description of the primary constituent elements it concludes are essential to the conservation of the species, and must define objective, measurable criteria for identifying such features. ${ }^{114}$

- The Service must identify only those specific areas on which the features essential for the conservation of the species are found, and in doing so may not include areas not affirmatively found to contain the essential features on the basis that they may later be removed with the benefit of more information. ${ }^{115}$

- The Service must articulate the particularized reasons why any specific area that does contain the essential features also presently requires, or in the future may require, special management considerations or protection. ${ }^{116}$

- The Service must define areas occupied by the species based on direct physical evidence of occupation rather than generalized assumptions about habitat conditions or species preferences. ${ }^{117}$

109 See Doremus, supra note 15, at 1082-87 (discussing controversy and litigation regarding failure by FWS to reveal the methodological basis for and underlying science in support of its decisions).

110268 F. Supp. 2d 1197 (E.D. Cal. 2003).

111 Home Builders Ass'n of N. Cal., 268 F. Supp. 2d at 1206 (acknowledging that APA standards of review apply); id. at 1224-25 (explaining the best scientific data available standard).

112 These methodological points are found in the court's extensive description of the agency's errors and are summarized in the court's conclusions. For the substantive criteria associated with critical habitat designation, see supra notes 51-52 and accompanying text.

113 Id. at 1214.

114 Id. at 1216.

115 Id. at 1210.

116 Id. at 1218.

117 Id. at 1221. 
- The Service must acknowledge evidence in the record that conflicts with its conclusions regarding the foregoing matters and provide a rationale for rejecting such evidence. ${ }^{118}$

The Professional Judgment Method, in other words, is more than the agency saying, "we're the experts, and that's the way we saw it." But how much more than that must it be? And, more the point of the next two Sections, how much more than that can the agency make it?

\section{B. The Scientific Method-Emphasis on "Best Scientific Data . . "}

Recently, I had the pleasure of taking part in an unprecedented event under the ESA. The national media followed the tumultuous events of ESA implementation in the Klamath River Basin, which straddles the OregonCalifornia border. ${ }^{119}$ There, for over one hundred years, the Bureau of Reclamation (BOR) has operated an irrigation water diversion project at dams impounding Upper Klamath Lake. Over that time, however, two species of sucker fish-the shortnose sucker (Chasmistes brevirostris) and the Lost River sucker (Deltistes luxatus) - now inhabiting lake and tributary habitat above the dam, and a population of coho salmon (Oncorhyncus kisutch) inhabiting the river and tributary system below the dam, have dwindled in population. They have been listed under the ESA and thus are monitored and protected under the watchful eyes of FWS (for the suckers) and NMFS (for the salmon). In 2001, a drought year, FWS and NMFS concluded that continued flow of irrigation water out of the system would jeopardize the species in violation of section 7 of the ESA. BOR closed the headgates, and hundreds of farms dried to dust. Following public outcry over this fish-versus-humans saga, the Secretaries of Commerce and the Interior asked the National Academy of Science's National Research Council (NRC) to convene a committee of experts to conduct a scientifically rigorous peer review of the agencies' respective decisions-the first ever to be conducted of a discrete decision of FWS or NMFS under the ESA. ${ }^{120}$

118 Id. at 1225.

119 This brief recitation of the history of events taking place in the Klamath River Basin is not intended to be comprehensive. It is derived from personal knowledge and my work on the National Research Council's Committee on Endangered and Threatened Fishes in the Klamath River Basin, which thoroughly studied the area's land-use and water management history. See National Research COUNCIL, Endangered and Threatened Fishes in the Klamath River Basin: Causes of DEcline AND STRATEgies For Recovery 46-94 (2004) [hereinafter KLAMATH COMMTTEE FINAL REPORT] (describing, in depth, the land-use and water management of the Klamath River area). Additional detail can be found in Doremus \& Tarlock, supra note 65; Reed D. Benson, Giving Suckers (and Salmon) an Even Break: Klamath Basin Water and the Endangered Species Act, 15 TUL. ENVTL. L.J. 197 (2002); Julia Muedeking, Taking the Heart of the Klamath Basin: Is It Free?, 8 Drake J. AgRIC. L. 217 (2003); Cori S. Parobek, Of Farmers' Takes and Fishes' Takings: Fifth Amendment Compensation Claims When the Endangered Species Act and Western Water Rights Collide, 27 HARv. EnVTL. L. REv. 177 (2003).

$120 \mathrm{I}$ also should mention a study that purported to conduct some level of scientific peer review of $43 \mathrm{HCP}$ incidental take permits FWS had issued under section 10 of the ESA through late 1997. See NATIONAL CENTER FOR ECOLOGICAL ANALYSIS AND SYNTHESIS \& AMERICAN INSTITUTE of Biological Sciences, Using Science in Habitat Conservation Plans (1999), available at http://www.nceas.ucsb.edu/nceas-web/projects/97KAREI2/hcp-1999-01-14.pdf. The methodology 
As a member of the NRC's Committee on Endangered and Threatened Species of the Klamath River Basin (Klamath Committee), I saw first hand the difference methodology can make to substantive decisions under the ESA. The Klamath Committee's initial charge was to "assess whether the [FWS and NMFS] biological opinions are consistent with the available scientific information." ${ }^{121}$ Notice that the statement of task did not ask the Klamath Committee to assess whether the biological opinions were "arbitrary and capricious." Scientists are generally trained to minimize the possibility of making Type I errors, of claiming the truth of a hypothesis when in fact it is false. Science does so through the rigors of the Scientific Method. As an essential part of the process, peer review involves "a documented, critical review performed by peers who are independent of the work being reviewed." 122 For many scientists, the peer review "process does not merely reflect the scientific method, it is the scientific method." ${ }^{123}$ The Klamath Committee, in other words, was not filling the shoes of a court on judicial review. Rather, we were asked, in effect, to subject a discrete agency decision to rigorous, independent, scientific peer review.

I place emphasis on the nature of the Klamath Committee's peer review because it is quite distinct from the peer review conducted under a policy that FWS and NMFS adopted in 1994 and have implemented with respect to species listing decisions. ${ }^{124}$ In the policy, the agencies explain that they will

of the study, however, did not produce a rigorous peer review of each HCP, and did not purport to apply the procedures usually associated with producing independent scientific peer review. See U.S. FiSH \& WILDLIFE SERVICE, U.S. FiSH AND WILDLIFE SERVICE'S RESPONSE TO AIBS/NCEAS'S STUdy, USING SCIENCE IN HABITAT CONSERVATION PLANS, available at

http://endangered.fws.gov/hcp/response.htm (last visited Apr. 11, 2004).

121 The "statement of task" for the Klamath Committee at this juncture thus was quite narrow, requiring that the group "review and evaluate the science underlying" the agencies' decisions and "assess whether the [decisions] are consistent with the available scientific information." NATIONAL RESEARCH COUNCIL, SCIENTIFIC EVALUATION OF BIOLOGICAL OPINIONS ON ENDANGERED AND THREATENED FISHES IN THE KLAMATH RIVER BASIN-INTERIM REPORT 32 (2002) [hereinafter KL.AMATH COMMITTEE INTERIM REPORT]. All discussion of the Klamath Committee's work in this Article reflects my personal views and not those of the NRC, the Klamath Committee, or any other member of the Klamath Committee.

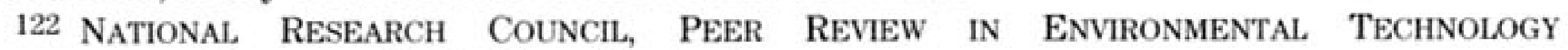
DEVElopment PRoGRAms 2 (1999), available at

http://print.nap.edu/pdf/0309063388/pdf_image/2.pdf. A peer is “'a person having. technical expertise in the subject matter to be reviewed (or a subset of the subject matter to be reviewed) to a degree at least equivalent to that needed for the original work.' Id. The peer's independence from the work being reviewed "means that the peer, a) was not involved as a participant, supervisor, technical reviewer, or advisor in the work being reviewed, and b) to the extent practical, has sufficient freedom from funding considerations to assure the work is impartially reviewed." Id. See also Office of Management and Budget, Peer Review and Information Quality, 68 Fed. Reg. 54,023, 54,024 (Sept. 15, 2003) (defining peer review as "a scientifically rigorous review and critique of a study's methods, results, and findings by others in the field with requisite training and expertise. Independent, objective peer review has long been regarded as a critical element in ensuring the reliability of scientific analyses.").

123 Lars Noah, Scientific "Republicanism": Expert Peer Review and the Quest for Regulatory Deliberation, 49 EmoRy L.J. 1033, 1045 (2000) (emphasis added).

124 Endangered and Threatened Wildlife and Plants: Notice of Interagency Cooperative Policy for Peer Review in Endangered Species Act Activities, 59 Fed. Reg. 34,270, 34,270 (July 1, 1994). 
"incorporate independent peer review in listing and recovery activities."125 This step, they explain, will involve "[s]olicit[ing] the expert opinions of three appropriate and independent specialists regarding pertinent scientific or commercial data and assumptions relating to the taxonomy, population models, and supportive biological and ecological information for species under consideration for listing." ${ }^{26}$ The problem is that, although the agencies reassuringly explain that "[i]ndependent peer reviewers should be selected from the academic and scientific community, Tribal and other Native American groups, Federal and State agencies, and the private sector," 127 and that "those selected have demonstrated expertise and specialized knowledge related to the scientific area under consideration,"128 it is the agencies that select their peer reviewers, review the peer reviews, and report the results of the peer reviews. ${ }^{129}$

Whether these conditions can ensure independent peer review is no idle concern. A recent study of how FWS has implemented the peer review policy noted that "Service officials told us that they have not adopted a formal procedure to assess peer reviewers' independence, and the Service does not publicly disclose ... potential conflicts or prior involvement by its peer reviewers" and concluded that other agencies "use more rigorous forms of peer review." ${ }^{130}$ The study also found that the people FWS chose to serve as peer reviewers usually agreed with the agencies' positions. ${ }^{131}$ Yet, with virtually no information at hand with which to test the independence of peer reviewers, one cannot reliably conclude from this seemingly strong track record whether FWS subjected its decisions to peer review and received consistently good marks, or simply sought peer approval and ensured the process would produce plenty. Even putting aside the possibility of selfserving motives, the agencies' peer review policy fits the type of sloppy, ad hoc model many find objectionable in administrative agency practice. ${ }^{132}$

Overall, therefore, the agencies' peer review policy may lead to review of FWS and NMFS decisions, perhaps by peers, and even by peers who are scientists, but its independence and objectivity is inherently suspect. By

125 Id.

$126 \mathrm{Id}$.

127 Id.

128 Id.

129 See, e.g., Endangered and Threatened Wildlife and Plants; Final Rule to Reclassify and Remove the Grey Wolf from the Endangered and Threatened Wildlife in Portions of the Conterminous United States; Establishment of Two Special Regulations for Threatened Grey Wolves, 68 Fed. Reg. 15,804, 15,819-20 (Apr. 1, 2003) (to be codified at 50 C.F.R. pt. 17) (discussing FWS's use of the peer review process in connection with a decision about the status of gray wolves (Canis lupus)).

130 U.S. General Accounting OfFICE, GAO-03-803, ENDANGEREd SpECIES: Fish AND WiLdLIFE Service Uses Best Avallable Science to MaKe Listing Decisions, But Additional Guidance NEEDED FOR CRITICAL HABITAT DESIGNATIONS 15-16 (2003), available at

http://www.gao.gov/new.items/d03803.pdf.

131 Id. at 21-22.

132 See, e.g., Office of Management and Budget, Peer Review and Information Quality, 68 Fed. Reg. 54,023, 54,024-25 (Sept. 15, 2003) (discussing the flaws in different federal agency peer review procedures that lead to reduced reliability and credibility of the reviews, but not going so far as to require NRC's appointment procedures, discussed infra note 133). 
contrast, the NRC peer review policy, under which the Klamath Committee was formed, provides:

The Research Council does not permit governmental agencies that sponsor projects to select committee members because of the institution's commitment to ensuring independence and objectivity in carrying out its work. However, sponsors can and often do suggest nominees, some of whom may be selected. Such a selection could be made when the individuals nominated by a sponsor have the expertise, knowledge, and stature required and can be expected to participate in a committee's work without being subjected to undue influence or pressure from the sponsoring agency. ${ }^{133}$

The initial results of the Klamath Committee's preliminary peer review, the so-called Interim Report, caught the attention of the three agencies and the other stakeholders. ${ }^{134}$ As noted, the specific charge for the interim report was to "consider to what degree the analysis of effects in the biological opinions . . . is consistent with [the available] scientific information." ${ }^{135}$ The Klamath Committee found, based on an independent, objective, scientifically rigorous review of available information in the available time period, that "no sound scientific basis" existed for the two central recommendations that FWS and NMFS made regarding the most controversial features of the Klamath Project - effects of lake levels and river flows on the fish. ${ }^{136}$ The Committee also found that BOR's proposed operational changes had no scientific basis. ${ }^{137}$

I do not point out that the Interim Report jarred the agencies and other interests in an effort to shine additional notoriety on the Klamath Committee. Rather, I use it to point out that the Scientific Method is more demanding than the Professional Judgment Method and may reveal gaps or flaws in agency decision making that would not be detected by, or even relevant to, conventional judicial review applied to decisions derived from the Professional Judgment Method. In other words, even though the agencies' biological analyses did not stand up to our scientific peer review, that does not dictate which set of agency decisions, if any, would have withstood judicial review. A court using the rules of judicial review would not, and could not, apply scientific peer review procedures to the agencies' decisions, and thus may have upheld FWS and NMFS, or BOR, or may not have upheld any of them. ${ }^{138} \mathrm{I}$ expect this would be true in many other

133 Nat'l Research Council, The National Research Council Process, at http://www.nationalacademies.org/about/faq4.html (last visited Apr. 11, 2004). Because of the consequences peer review would have under my proposal with regard to judicial review, see infra Section V, I would require that the NRC appointment procedures be used.

134 See KL.AMATH COMmTtTeE INTERIM REPORT, supra note 121, at 3-4 (summarizing the Committee's principal findings that the agencies had no scientific basis for requiring increased lake levels or increased stream flow).

135 See supra note 121 (describing Klamath Committee's charge).

136 See Klamath COMMITTEE InTERIM REPORT, supra note 121, at 3-4 (finding no scientific evidence supporting requirement of increased lake levels or increased stream flow).

137 Id. at 4-5.

138 My personal view is that it is almost certain a court would have upheld the FWS and 
discrete decision settings under the ESA, and thus take some issue with Professor Holly Doremus's comparison of peer review and the conventional rules of judicial review, in which she suggests that peer review in the ESA generally would provide only as coarse a filter for detecting error as is already supplied under the conventional rules of judicial review. ${ }^{139}$ Granted, we have only one experience-the Klamath Committee-from which to draw conclusions, but it does suggest the peer review filter can be considerably finer than the judicial review filter.

What does this have to say about the ESA? Following publication of the Interim Report, some agitators used it to support charges that the ESA is "scientifically flawed" in that it allows the agencies to work on the basis of so-called "junk science." ${ }^{140}$ Nonsense. If that charge is true, it is true of virtually every other environmental law, for any decision-making process that operates under the Professional Judgment Method is bound eventually to make mistakes that would have been avoided under the Scientific Method (or, for that matter, under the Precautionary Principle Method). Rather, all the Interim Report demonstrates in the way of broader policy questions is that there is a decision to be made about methodology, about where on the hierarchy of decision grounds we want FWS and NMFS to operate. All the Klamath Committee revealed is that the agencies, while perhaps exercising sound professional judgment in their biological opinions (something the Klamath Committee was not asked to decide), did not produce a decision that passed Scientific Method peer review. Anyone who charges the agencies with practicing "junk science" on that basis either has no idea what "good science" is or is simply being dishonest about their true intent-to influence the substantive outcomes of the ESA process by demanding the agencies satisfy the Scientific Method. As the Klamath Committee observed in its second report, the so-called Final Report, ${ }^{141}$

[A]gencies charged with ESA responsibilities can be expected to use professional judgment when no scientifically supportable basis is available for a decision, or where they judge the scientific support to be inadequate. Thus, the agencies may recommend practices for which the committee would find

NMFS biological opinions as not arbitrary and capricious. That likelihood was severely diminished, if not reversed, by the Klamath Committee's Interim Report, though events have overtaken the possibility of that precise question ever being decided.

139 See Doremus, supra note 15, at 1146-47. To be fair, she focused her remarks on the style of peer review used to screen journal articles and grant proposals, which is not nearly as rigorous as the level of peer review the Klamath Committee employed or that is envisioned in most scientific agency usages. See supra note 122 (discussing standards of peer review).

140 See Doremus \& Tarlock, supra note 65, at 333-34 (connecting the desire for easier economic development with more stringent scientific support for endangered species protection). The Klamath Committee also was the target of much criticism and, in general, the situation deteriorated into what some observers referred to as "combat biology." Robert F. Service, Combat Biology on the Klamath, 300 SCIENCE 36, 36 (2003). The lack of established structure for carrying out the peer review probably contributed to the ways in which the findings were used and abused, and that is one reason for my proposal infra.

141 KLAMATH COMMITTEE FINAL REPORT, supra note 119. After completing the Interim Report, the Klamath Committee's charge broadened the study's focus to include a more comprehensive assessment of the recovery needs of species in the basin. 
virtually no direct scientific support. The committee acknowledges the necessity of this practice in many situations where information is inadequate for development of scientifically rigorous decisions. ${ }^{142}$

Alas, many simply cannot live with the risk of Type I error and thus demand more from the agencies. Such a demand was embodied in the "Sound Science for Endangered Species Act Planning Act of 2002," which Representative James Hansen (R-Utah) introduced on May 23, 2002, as one in a long line of so-called ESA "sound science" bills. ${ }^{143}$ In general, this and similar "sound science" proposals ${ }^{144}$ would alter the procedures, standards of evidence, and burdens of proof under which federal agencies operate in carrying out ESA programs. The legislation would "raise the bar" for ESA procedures in many respects, requiring FWS and NMFS to give preference to certain forms of evidence and apply more rigorous burdens of proof to a long list of specified decisions. In particular, the bill would institute a more formal and probing peer review step for many more ESA decisions than the agency has imposed on itself under the 1994 policy. These changes likely would increase the procedural and financial burdens associated with carrying out the affected functions. Assuming sufficient resources to allow the agencies to carry out diligently the new requirements-a big assumption-it is possible that, by enhancing the evidentiary record and burden of proof, the changes would reduce agency error in carrying out those functions.

Like almost any bill proposing to tinker with the ESA, H.R. 4840 enjoyed strong support ${ }^{145}$ and engendered equally strident criticism. ${ }^{146}$ The Bush Administration generally supported the bill with only minor suggested changes. ${ }^{147}$ The House Resources Committee held hearings on the bill in

142 Id. at 35. Methodology battles nonetheless continue to play out in the Klamath. Recently, for example, a court found that FWS improperly declined to engage in further review of a petition to delist two species of sucker fishes found in the Klamath Basin. Moden v. United States Fish \& Wildlife Serv., 281 F. Supp. 2d 1193, 1196 (D. Or. 2003). In Moden, one federal agency study showed sucker populations had rebounded, but a later study by FWS failed to confirm that trend. Id. at 1204. The two studies used substantially different methodologies, and FWS found the prior study "uninformative" because it "used an extremely different methodology." Id. at 1205. The court faulted FWS, however, for failing to explain the differences in methodologies and why the prior study's methodology did not support the petition to delist the species. Id.

143 H.R. 4840, 107th Cong. (2d Sess.) (2002).

144 For a more recent version, see S. 369, 108th Cong. (1st Sess.) (2003), and H.R. 1662, 108th Cong. (1st Sess.) (2003).

145 See, e.g., National Endangered Species Act Reform Coalition, H.R. 4840, the Sound SCIENCE FOR ENDANGERED SPECIES ACt PlaANING ACT OF 2002, at http://www.nesarc.org/walden.htm (last visited Apr. 10, 2004) (providing links to several relevant sites).

146 See, e.g., Press Release, Defenders of Wildlife, Statement by Rodger Schlickeisen, President of Defenders of Wildlife, on Committee Markup HR 4840, a Bill that Purports to Offer "Sound Science" for ESA (July 11, 2002) (calling the proposal "one more effort by the 'development at any cost' crowd to gut the ESA"), available at http://www.defenders.org/releases/pr2002/pr071102.html .

147 See generally Division of CONGREsSIONAL AND LEgISLATIVE AFFaIRS, U.S. Fish \& WILDLIFE Service, Fish AND WildLife Service Testimony Before the 107Th Congress, at 
June $2002^{148}$ and reported it favorably on July 10,2002 in a 22-18 vote that followed party lines. ${ }^{149}$ It is likely a good indication of what we may expect in upcoming sessions of Congress in the way of efforts to make the ESA more "scientific" in method.

Notably, however, most of these "sound science" bills apply their version of science primarily to agency decisions that involve the extension of protection to species, such as listing of species under section 4 and the finding of jeopardy under section 7 , and not to decisions to allow development, such as the issuance of incidental take permits under section 10. ${ }^{150}$ The "sound science" bill proponents could hardly commit a more obvious tipping of the hand, reserving peer review for the decisions they dislike the most with the clear intent of altering the substantive outcome by beefing up the methodological standard. To be even-handed in this criticism, though, studies have shown that support for peer review under the ESA, which is strong in both the industry and the environmental camps, is almost always limited to applying the review to the type of decisions each interest group finds the most troublesome. Dr. Deborah Brosnan found, for example, that more than sixty prominent lobbying groups representing a diverse array of interests actively supported using peer review under the ESA, but that "each group favors review of actions that it finds unpalatable. Development groups want fewer species listings and therefore demand review of listing decisions. ... Environmental groups are concerned about habitat loss under HCPs and want them independently reviewed."151

Yet, even if Congress were to sufficiently fund FWS and NMFS to allow them to practice genuine sound science across the board, the Scientific Method would strangle the ESA to death. If the Scientific Method were enforced under the ESA for listing and jeopardy decisions, the lack of complete data about imperiled species, compounded by the lack of time sufficient to collect more complete data before the possibility of extinction grows larger, would create a structural risk asymmetry in the ESA under which "the probability that the species will not be protected when protection

http://laws.fws.gov/testimon/2001/main2001.html (last visited Apr. 11, 2004). "Sound science" has become a theme across many programs in the Bush Administration. See Summary of Fiscal Year 2004 Budget Request Prepared by EPA, 34 Env't Rep. (BNA) S-112 to S-121 (2003) (reproducing EPA's February 3, 2003, summary of its proposed budget including "Goal 8," which is described as "Sound Science, Improved Understanding of Environmental Risk and Greater Innovation to Address Environmental Problems").

148 Hearing of the House Resources Comm., Subcomm. On Fisheries Conservation, Wildlife and Oceans on H.R. 4781 The Marine Mammal Prot. Act Amendments of 2002 (2002), available at http://www.legislative.noaa.gov/Archives/2002/hogarthhearingreport061302.pdf.

149 E.g., Legislative Alert, Nat'l Endangered Species Act Reform Coalition, ESA Victory: Sound Science Legislation Passes House Resources Committee (July 11, 2002), available at http://www.nesarc.org/4840alert.pdf.

150 See supra note 151 and accompanying text (describing how this result is consistent with Hypothesis Statement Framework).

151 Deborah M. Brosnan, Can Peer Review Help Resolve Natural Resource Conflicts?, 16 ISSUES IN SCI. AND TECH. 32, 33 (2000). This pattern of methodological preference matches up perfectly with the preferences one would expect to observe under the Hypothesis Statement Framework. See infra Section II.B. 
is needed is greater than the probability that the species will be protected unnecessarily." ${ }^{152}$ In other words, some species simply do not have the time that the Scientific Method demands. Indeed, the deadlines Congress has placed in the ESA on agency decision making acknowledge the pressing need in many cases to intervene quickly on behalf of species, lest they vanish before we decide what to do. ${ }^{153}$ Over time, therefore, we will experience more Type II errors than Type I errors by applying the Scientific Method to listing and jeopardy decisions-more species that should have been protected, but were not, than those which should not have been protected, but were.

Of course, the same asymmetry would arise if the Scientific Method applied to all HCP decisions. In that context, however, the Type II error experienced would lead to unnecessary socioeconomic losses. Land development, like the management of imperiled species, is often time sensitive given fluid market conditions. Subjecting an HCP to the rigors of peer review and higher burdens of proof would add time and cost to the HCP process, thus crowding out some otherwise worthy applicants. While environmentalists might not lose sleep over the possibility, property rights advocates would, and the ESA likely would suffer additional loss of integrity in Congress and even within moderate economic interest groups.

The advantage of the Professional Judgment Method is that it releases FWS and NMFS from the chains of the Scientific Method. ${ }^{154}$ It allows them to draw on professional experience to spot conditions suggesting a high probability of Type II error and to take appropriate action notwithstanding the lack of conclusive evidence refuting the possibility of Type I error. ${ }^{155}$ The quest to avoid Type I error, while appropriate for scientific endeavors, will not always be appropriate for policy endeavors, and thus ought not prevent the agencies from making smart decisions. Alas, those who advocate the Precautionary Principle Method as the solution to this problem go furtherthey wish to bind the agencies with a different set of shackles.

152 SCIENCE AND THE ESA, supra note 12 , at 167.

153 See supra note 7 (describing deadline to designate critical habitat).

154 There is a growing consensus that following pure science is not always, perhaps seldom, good environmental policy. See Doremus, supra note 15, at 1129 (criticizing the ESA's "strictly science" mandate); A. Dan Tarlock, Who Owns Science?, 10 PENN ST. ENVTL. L. REV. 135, 138-39 (2002) (addressing the challenges of combining science and environmentalism); see generally Adam Babich, Too Much Science in Environmental Law, 28 ColuM. J. ENVTL. L. 119 (2003).

155 As has been observed in this context:

In some cases, there is very little "hard" information that seems relevant to estimating the risks affecting endangered species, but some experts have accumulated experience that allows them to make informed judgments about these risks. Such expert judgment is so often available for endangered species decisions that it is of great benefit to have orderly methods of eliciting and using it for decision making.

SCIENCE AND THE ESA, supra note 12, at 158. 


\section{The Precautionary Principle Method-Emphasis on \\ "Best. . . Data Available"}

The Klamath Committee received numerous comments from members of the public regarding the issue of "burden of proof" and suggesting that the ESA imposes, or should impose, a "precautionary principle" burden on resource users. ${ }^{156}$ According to these comments, based on this methodological approach the Interim Report improperly assumed that the burden of demonstrating harm should be on the fish and wildlife agencies, and not on the Klamath Project users to demonstrate benefits. ${ }^{157}$ These comments mistook not only the charge of the Klamath Committee in the Interim Report, but also the issue of methodology altogether.

First, the Klamath Committee's evaluation of the agencies' consultation positions was defined by its charge, which required the Committee to assess "whether the biological opinions are consistent with the available scientific information." The Committee therefore was required to adopt the burden of proof that would apply in the peer review method employed in the scientific community, not whatever legal burden of proof applies under the ESA. It is not necessarily the case in any setting that scientific proof burdens and legal proof burdens are coterminous. This burden of proof issue pervades the ESA, where "the science" and "the law" frequently intersect. Yet, while these disciplines intersect in the ESA context, they do not conflate into one and the same. Keeping them separate is important for purposes of ensuring proper implementation of scientific peer review and of science in general.

Second, the "precautionary principle" is a decision-making policy instrument, not a scientific standard of proof. It represents an entirely different methodology for that reason, albeit as a policy method it is tied closely to the issue of how to manage scientific evidence and uncertainty. As several commenters pointed out to the Klamath Committee, application of a precautionary principle in the ESA context was discussed in the NRC's 1995 report, Science and the Endangered Species Act, in which another NRC Committee outlined the way in which such an approach could be applied to species conservation decision making under the ESA. ${ }^{158}$ But nothing in Science and the Endangered Species Act suggests that the prior NRC committee believed that the precautionary principle is methodologically mandated for decision making under the ESA, or is an essential feature of science or scientific peer review. Quite simply, whether to apply the precautionary principle is a policy decision, the evaluation of which was within the scope of the charge of the NRC Committee that prepared Science and the Endangered Species Act ${ }^{159}$ However, it was outside the scope of the

\footnotetext{
156 See KLAMATH COMmtTteE FinAL REPORT, supra note 119, at 314-16 (discussing viewpoints on burden of proof and the precautionary principle).

157 Id.

158 See SCIENCE AND THE ESA, supra note 12, at 169.

159 The charge for the NRC Committee that prepared Science and the ESA included the request that the Committee provide "a review of whether different levels of risk ought to apply to different types of decisions (and the practical methods that might be employed to assess risk) to better achieve the purposes of the Act while providing flexibility in appropriate
} 
Klamath Committee's charge pertaining to "whether the biological opinions are consistent with the available scientific information." 160

Beyond that, any argument that the ESA requires using the Precautionary Principle Method generally or in any of its specific programs is on thin ground. ${ }^{161}$ To be sure, many substantive programs of the ESA, such as the prohibition of jeopardy and the restriction against take, are precautionary in orientation. But substantive programs are not the same as methodological approaches, which is the whole point of why there is an ongoing debate over ESA methodology. It is settled that the ESA programs are substantively designed to treat imperiled species with caution. But it is far from settled how, methodologically, the agencies are to implement those substantive programs. Given the extensive socioeconomic costs associated with the ESA, there would be nothing inconsistent or irrational about prohibiting federal agencies from jeopardizing the continued existence of a listed species, but demanding that FWS and NMFS produce rigorous proof that jeopardy will occur before shutting down a federal project. Simply put, the fact that the substantive prohibitions against jeopardy and take sprang from congressional caution ${ }^{162}$ does not mean that Congress codified the Precautionary Principle Method for implementing them.

On that methodological question, a fleeting passage in the conference report accompanying the 1979 amendments to the section 7 jeopardy consultation provisions suggests that Congress believed the agencies should, or at least could, "give the benefit of the doubt to the species" when information is not conclusive on the jeopardy question. ${ }^{163} \mathrm{In}$ its full context, however, the "benefit of the doubt" reference is ambiguous, for the overall intent of the amendments clearly was to relieve FWS and NMFS of any cause for believing they must find jeopardy when the action agency fails to provide conclusive evidence of nonjeopardy. ${ }^{164}$ In other words, the amendment

circumstances to accommodate other objectives as well." SCIENCE AND THE ESA, supra note 12, at 208.

160 That said, my proposal infra is designed to accomplish what is charged as lacking in the Klamath Committee's work-i.e., to apply peer review to agency decisions explicitly to employ the Precautionary Principle Method, with the standard of review being whether there was a sound basis for concluding that Type II error consequences were substantially probable and severe. This would be a fundamentally different charge from the one under which the Klamath Committee operated.

161 I have also examined this issue in connection with work exploring the pragmatic qualities of the ESA. See Ruhl, supra note 104, at 917-18. See also Kl.AMATh COMmitTEE Final REPORT, supra note 119 , at 314-16.

162 See, e.g., H.R. REP. No. 93-412, at 5 (1973) ("The institutionalization of that caution lies at the heart of [the ESA]."); 119 CoNG. REc. 42,913 (1973) (floor debate statement of Rep. Dingell) ("[W]e should act cautiously.").

163 See H.R. CONF. REP. No. 96-697, at 12 (1979), reprinted in 1979 U.S.C.C.A.N. 2557, 2576.

164 The conference report describes congressional intent in adopting the "best scientific data available" standard in the section 7 consultation process as follows:

As currently written ... the law could be interpreted to force the Fish and Wildlife Service and the National Marine Fisheries Service to issue negative biological opinions whenever the action agency cannot guarantee with certainty that the agency action will not jeopardize the continued existence of the listed species or adversely modify its critical habitat. The amendment will permit the wildlife agencies to frame their section 
reduced whatever basis there was in prior law for applying the Precautionary Principle Method. ${ }^{165}$ Nevertheless, FWS and NMFS have relied on the conference report passage to endorse a version of the "benefit of the doubt" principle twice-first in their preamble explanation of rules adopted in 1986 for conducting section 7 consultations, ${ }^{166}$ and more recently in their internal guidance on how to conduct consultations. ${ }^{167}$ And two courts have gone so far as to impose the "benefit of the doubt" concept where incomplete or inconclusive information required the agency to make a close call, one with respect to a jeopardy consultation decision ${ }^{168}$ and another with respect to a listing decision. ${ }^{169}$ NMFS has also on occasion announced in listing and jeopardy consultation decisions that it would provide that benefit

7(b) opinions on the best evidence that is available or can be developed during consultation. If the biological opinion is rendered on the basis of inadequate information then the federal agency has a continuing obligation to make a reasonable effort to develop that information.

This language continues to give the benefit of the doubt to the species, and it would continue to place the burden on the action agency to demonstrate to the consulting agency that its action will not violate section $7(\mathrm{a})(2)$.

Id. at 2576. Notably, I have found no other reference to the "benefit of the doubt" principle in any legislative history of the ESA or its amendments.

165 As one court put it, after the 1979 amendments it is clear that "neither the statute nor the regulations ... prohibit[] agency action when the information necessary to establish jeopardy is unavailable." Vill. of False Pass v. Watt, 565 F. Supp. 1123, 1154 (D. Alaska 1983), aff'd sub nom. Vill. of False Pass v. Clark, 733 F.2d 605 (9th Cir. 1984).

166 See Interagency Cooperation-Endangered Species Act of 1973, As Amended; Final Rule, 51 Fed. Reg. 19,926, 19,952 (June 3, 1986) ("[T]he Service must provide the 'benefit of the doubt' to the species concerned."). The regulatory text governing section 7 consultations, however, contains no such principle. See 50 C.F.R. pt. 402 (2004).

167 See U.S. Fish \& Wildilfe Service and Nat'l Marine Fisheries Service, Endangered Species Consultation HandBOOK: Procedures fOR CONDUCTING Consultation and CONFERENCE ACTIVITIES UNDER SECTION 7 OF THE ENDANGERED SPECIES ACT 1-6 (1998), available at http://endangered.fws.gov/consultations/s7hndbk/s7hndbk.htm. The handbook, which is nonbinding, references the conference report in explaining that, where there is insufficient information for FWS or NMFS to fulfill its duty of providing a biological opinion to the action agency and the action agency does not agree to provide more time for development of information, FWS or NMFS will "develop the biological opinion with the available information giving the benefit of the doubt to the species." Id.

168 See Conner v. Burford, 848 F.2d 1441, 1452 (9th Cir. 1988) (FWS must "give the benefit of the doubt to the species" and find jeopardy when FWS concluded that there was "insufficient information available to render a comprehensive biological opinion" concerning oil and gas leases.). More recently, however, the same court held that it is not error for the agency to reach a nonjeopardy opinion, thus allowing a proposed action to proceed under section 7 , even in the face of scientific uncertainty about its consequences for the species. See Greenpeace Action v. Franklin, 14 F.3d 1324, 1337 (9th Cir. 1992) ("The Service's decision to go ahead with the [proposed action], despite some uncertainty about the effects of [the proposed action] on the [species], was not a clear error of judgment."). The only other court to mention the "benefit of the doubt" principle in the section 7 context did so approvingly, but in dicta that was not consequential to the outcome of the case. See Greenpeace v. Nat'l Marine Fisheries Serv., 55 F. Supp. 2d 1248, 1262 (W.D. Wash. 1999).

169 See Defenders of Wildlife v. Babbitt, 958 F. Supp. 670, 677 (D.D.C. 1997) (FWS must "give the benefit of the doubt to the species" and list the Canada lynx (Lynx canadensis) despite FWS's claim that there was not "substantial information that the southern Rocky Mountain population of the Canada lynx meets the definition of a 'species."'). 
of the doubt to the species or, in the same spirit, would "err on the side of the species" because of close evidentiary calls. ${ }^{170}$

Beyond these few brief encounters, which seem to take the legislative history farther than is justified, there is no foundation on which to build a case that the Precautionary Principle Method applies as the default methodology in any ESA program, and the agencies have not voluntarily adopted it as formal policy. ${ }^{171}$ Moreover, no case can be made that the courts have imposed a de facto Precautionary Principle Method by striking down agency decisions not to list or protect species-there are equally as many cases striking down decisions to list a species or extend protection. ${ }^{172}$ Although the Supreme Court once described the ESA as "institutionalized caution,"173 its more recent admonition that the "best scientific data available" standard is "intended, at least in part, to prevent uneconomic (because erroneous) jeopardy determinations"174 suggests that the standard

170 See, e.g., Regulations Governing the Approach to Humpback Whales in Alaska, 66 Fed. Reg. 29,502 (May 31, 2001) (promulgating regulations under the ESA governing the approach of listed whales, in part to implement a precautionary principle approach); Endangered Status for Snake River Sockeye Salmon, 56 Fed. Reg. 58,619 (Nov. 20, 1991) (deciding to list a population of salmon notwithstanding uncertainty as to whether it was genetically distinct from other populations); NAT'L Marine Fisheries SERVICE, SECTION 7 Consultation Biological Opinion AND INCIDENTAL TAKE STATEMENT FOR BERING SEA/ALEUTIAN ISLANDS GROUNDFISH FISHERIES 133 (Oct. 19, 2001) (explaining that the agency conducted the consultation by all times giving the "benefit of the doubt" to the species), available at

http://www.fakr.noaa.gov/protectedresources/stellers/biop2002/sec7_ssl_protection_measures_ final.pdf; NAT'L MARINE Fisheries SERVICE, SECTION 7 CONSUltation Biological Opinion ON Atlantic Highly Migratory Species Fishery Management Plan 99 (2000) (explaining that in selecting takes of turtles from specified activities the agency would "err on behalf of the species"), available at

http://www.nmfs.noaa.gov/prot_res/readingrm/ESAsec7/HMS060801final.pdf; see also Or. Natural Res. Council v. Daley, 6 F. Supp. 2d 1139, 1149 (D. Or. 1998) (quoting an NMFS official's rationale for recommending listing of a population of salmon as being the "err on the side of the species" principle).

171 At least one court has rejected the argument that the section 7 consultation handbook FWS and NMFS have prepared as internal guidance, supra note 167, constitutes official agency policy. See Nat'l Wildlife Fed'n v. Babbitt, 128 F. Supp. 2d 1274, 1300 (E.D. Cal. 2000). Moreover, other than the instances referred to above, I have found no instances in which either FWS or NMFS so much as uses phrases such as "precautionary principle," "benefit of the doubt," or "err on the side of the species" in any official ESA decision document. In addition to traditional legal research methods, in October 2002 I conducted searches for these word combinations in both agencies' records using search engines on their web sites. See U.S. FiSH \& WILDLIFE SERVICE, SEARCH THE ENDANGERED SPECIES PROGRAM SITE, at http://endangered.fws.gov/search.html (last visited Apr. 11, 2004); NAT'L MARINE Fisheries SERvice, NOAA Fisheries-Search THE FISHERIES, at http://www.nmfs.noaa.gov/search.htm (last visited Apr. 11, 2004). I found no additional instances. While this may not represent a comprehensive set of available records, one would expect that if the agencies have widely used these phrases to represent general adoption of a precautionary principle as a matter of ESA implementation policy, more instances would have appeared. This is reinforced by the fact that one or more of the phrases did appear in numerous other documents implementing or associated with other authorities the two agencies administer.

172 See Ruhl, supra note 39, at 28-33; U.S. GENERAL ACCOUNTING OFFICE, supra note 130, at 22-24 (reviewing cases).

173 Tenn. Valley Auth. v. Hill, 437 U.S. 153, 194 (1978).

174 Bennett v. Spear, 520 U.S. 154, 177 (1997). 
is at least as precautionary with respect to socioeconomic interests as it is to species conservation interests. ${ }^{175}$ This balance would put the "best scientific data available" squarely in the realm of the Professional Judgment Method, which is how the vast majority of courts have interpreted the standard. ${ }^{176}$

In that respect, however, it does appear to be within the discretion of the FWS and the NMFS to make a decision that errs on the side of the species when confronted with substantial but inconclusive and conflicting data about such matters as whether a species deserves listing or whether a proposed action is likely to cause jeopardy. Any student of administrative law knows that courts generally defer to the agency's choice in close-call cases, where some record evidence exists to support a decision in either direction and the statute imposes no default position. ${ }^{177}$ There are likely to be many instances in which FWS and NMFS will be justified in exercising more precaution than normal on the basis of incomplete information. For example, in its recent study of incidental take permits, the Defenders of Wildlife suggested that whether the listing agency has promulgated a recovery plan for a listed species under section $4(\mathrm{f})$ of the $\mathrm{ESA}^{178}$ should influence how precautionary the agencies' approach to incidental take permit decisions under section 10 of the statute should be. ${ }^{179}$ Listing decisions collect information about a species decline, whereas recovery plans collect information about how to improve a species' viability. ${ }^{180}$ Thus, the advocacy group explained:

Clearly, HCPs ... must move forward in the absence of updated recovery plans. When recovery plans are not available, however, conservation plans should incorporate the precautionary principle strategy. That is, conservation plans should have better protection for species, to make up for uncertainties stemming from inadequate information and missing recovery plans. ${ }^{181}$

175 To be sure, the agencies cannot throw caution to the wind when it comes to species conservation. Several courts, for example, have admonished FWS for relying on nonbinding commitments of future conservation measures as the basis for reaching nonjeopardy opinions with respect to projects being proposed for immediate completion. See, e.g., Nat'l Wildlife Fed'n v. Nat'l Marine Fisheries Serv., 254 F. Supp. 2d 1196, 1211 (D. Or. 2003) (holding that NOAA's conclusion of no jeopardy was arbitrary and capricious).

176 See Brennan et al., supra note 79, at 412-32 (presenting a thorough review of cases interpreting the "best scientific data available" standard); U.S. GENERAL ACCOUNTING OFFICE, supra note 130 , at 22-24, 30-31 (reviewing cases and noting discretion inherent in deciding what is best science).

177 See supra note 27 and accompanying text (demonstrating the deference courts give to agency determinations).

178 Section 4(f) requires the listing agency to "develop and implement plans (hereinafter in this subsection referred to as "recovery plans") for the conservation and survival of endangered species and threatened species." 16 U.S.C. $\$ 1533(\mathrm{f})(1)(2000)$.

179 Defenders of Wildlife, Frayed SaFETy NetS: Conservation PlaAnNing Under the ENDANGERED SPECIES ACT 54 (1998) [hereinafter FRAYED SAFETY NETS].

180 Recovery plans are required to include "site-specific management actions" and "objective, measurable criteria" for the conservation of the species. 16 U.S.C. $\$ 1533$ (f)(1)(B)(i)-(ii) (2000).

181 FraYed SAFETY NETS, supra note 179, at 54. See also Gregory A. Thomas, Where Property Rights and Biodiversity Converge Part III: Incorporating Adaptive Management and the 
Implementing tools of the Precautionary Principle Method, in other words, often may be consistent with the sound professional judgment of the agencies and thus within their legal discretion. Even in exercising this form of discretion, however, the agencies must be cautious for their own interests as well. Using their discretion to implement the Precautionary Principle Method will often put the agencies in precarious positions. The precautionary principle might be an appropriate policy decision for some cases under the ESA, but not for others. The challenge is sorting the former from the latter. ${ }^{182}$ Just as the Scientific Method can easily fall prey to abuse, the Precautionary Principle Method also has its potential dark side. At its most extreme aversion to Type II error, for example, the precautionary principle could more appropriately be called the "catastrophe principle." Under this application, if we can identify a proposed action (e.g., release of water to irrigators) and an environmental effect of that activity which, if experienced, would be catastrophic (e.g., the extinction of a species), then the imposition of the precautionary remedy is justified regardless of the probability that the activity causes the effect-even if it is "merely possible." 183 A precautionary approach less extreme on its face, but just as intolerant in effect, relies on complex theories of causation to postulate the feared Type II event and shifts the burden of disproving the causal chain to anyone advocating against the precautionary response. In the ESA context, for example, a proposed use of land could be tied to a postulated series of "causally related" events that could lead to death of an endangered animal, and thus the land use should not be allowed. ${ }^{184}$ These approaches, of course, erect impossible evidentiary barriers, as the capacity to disprove conclusively the possibility of Type II error events is not within reach of even rigorous scientific methods. Indeed, by discounting the value of science, these strong versions of the precautionary principle would reward ignorance. $^{185}$

Both of these strong variants of the Precautionary Principle Method are transparent in their aversion to the conventions of administrative process and judicial review. ${ }^{186}$ Neither FWS nor NMFS has suggested that it would

Precautionary Principle into HCP Design, 18 ENDANGEREd SPECIES UPdATE 32, 35-36 (2001) (presenting a similar, but more detailed, proposal).

182 See Ruhl, supra note 104, at 897-98 (examining problem relative to work exploring the pragmatic qualities of the ESA).

183 Neil A. Manson, Formulating the Precautionary Principle, 24 EnvTL. ETHICs 263, 270 (2002).

184 See, e.g., Morrill v. Lujan, 802 F. Supp. 424, 432 (S.D. Ala. 1992) (rejecting theory that after their construction, a night club and parking lot would attract cats who would cross a highway and cause harm to protected mice).

185 See Charnley \& Elliott, supra note 22, at 10,365 (2002) ("There is a danger that if applied in the extreme, the precautionary principle will be used as a license to ignore [the] ... elements of risk management decisionmaking."); Manson, supra note 183, at 274 (proposing that the precautionary principle should include "some sort of pledge to continue research, for otherwise the formulation might have the effect of rewarding ignorance”).

186 See Charnley \& Elliott, supra note 22, at 10,364 ("The rise of the precautionary principle can be viewed as an objection to the U.S. legal tradition of extensive administrative law requirements and court review of the factual basis of government decisions about 
consider adopting these fallacious approaches as the default principle for implementing the ESA, and likely no court would let them. But even selective use of the precautionary principle poses an ever-present risk to the agency of drifting from "precautionary" to the arbitrary. Indeed, two recent ESA cases show all too well how an agency can get carried away with the precautionary reflex, crossing the line into arbitrary behavior.

In the first, Defenders of Wildlife v. Flowers, ${ }^{187} \mathrm{FWS}$ demanded that the Army Corps of Engineers (Corps) engage in consultation under section 7 to determine the effects on a protected owl species of a development project for which the Corps proposed granting a permit under section 404 of the Clean Water Act. ${ }^{188}$ The Corps conducted extensive studies of the matter and determined that "[t]he proposed action does not reasonably rise to the level of effect that would trigger federal agency consultation with USFWS." 189 FWS, however, insisted on conducting a consultation based on its belief that "the proposed project would disrupt habitat connectivity, thus hindering the ability of the project area to serve as a movement corridor."'190 FWS presented no empirical evidence of this assertion, other than the proximity of the project to occupied habitat and the distinctly precautionary conclusion that "it is reasonable to assume that [owls] may have used the property at sometime in the recent past and would continue to do so in the future." 191 This went too far on behalf of precaution in the face of opposing scientific evidence, however, as the court concluded that "the Corps considered the relevant factors based upon voluminous scientific data before it, reasonably rejected the undocumented assertions made by the USFWS, and articulated a rational connection between the facts and its decision to make a 'no effect' determination." 192

In another recent case involving the same protected owl, National Ass'n of Home Builders v. Norton, ${ }^{193}$ the Ninth Circuit found that FWS had erred in listing the species in the first place. FWS listed the owl in question-a population of the cactus ferruginous pygmy-owl (Glaucidium brasilianum cactorum) found in Arizona-as a distinct population segment, which required FWS to find that the population had marked genetic distinctness significant to its taxon. ${ }^{194}$ Yet FWS could present no scientific evidence of marked genetic distinctness, and instead based its listing "on the potential for genetic distinctness. ${ }^{195}$ Again, however, FWS's precaution in the face of the agency's lack of scientific support or contrary scientific evidence went

\footnotetext{
environmental risks.").

187 No. CIV02195TUCCKJ, 2003 WL 22143266 (D. Ariz. Aug. 18, 2003).

$188 \mathrm{Id}$. at *2. Section 404 is codified at 33 U.S.C. $\$ 1344$ (2000).

189 Id. at $* 3$.

190 Id. (quoting Letter from David L. Harlow, Field Supervisor, U.S. Fish \& Wildlife Serv., U.S. Army Corps of Engineers' Administrative Record 005123 (Sept. 29, 1999)).

191 Id. at *4 (quoting Letter from David L. Harlow, Field Supervisor, U.S. Fish \& Wildlife

Serv., U.S. Army Corps of Engineers' Administrative Record at 005375).

192 Id. at $*$.

193340 F.3d 835 (9th Cir. 2003).

194 Id. at 839-40.

195 Id. at 850-51 (emphasis added).
} 
too far. The court noted that "FWS was not even sure if the genetic differences . . . were actual, let alone appreciable, ${ }^{196}$ and thus found that the agency acted arbitrarily and capriciously. ${ }^{197}$

These cases illustrate that although ad hoc use by FWS and NMFS of the Precautionary Principle Method perhaps protects species from risk, it is risky for the agency. When precaution drifts below the point where the agency's level of confidence is positive, operating in a data vacuum, or even in the face of counter-evidence, even deferential judicial review standards present a dangerous trap for the agency. Precaution is a well-understood instinct, but in regulatory contexts such as the ESA it lacks the structural decision-making framework that science supplies to the Scientific Method. This makes it difficult for the agency to guard even good faith use of precaution against the onslaught of arguments based on "science." I would not propose that courts treat such cases otherwise. Rather, I propose a structure for using the Precautionary Principle Method and Scientific Method in unison, in a way that could have avoided the results in Flowers and Home Builders, and maybe even in the Klamath River Basin.

\section{HARMONIZING THE THREE METHODOLOGIES}

I will pause here to emphasize the several important points made above. First, the precautionary principle is policy, not science. Conversely, science is science, not policy. The ESA, however, maps an intersection of science and policy. It is appropriate, therefore, that neither the Scientific Method nor the Precautionary Principle Method is the exclusive law of the ESA.

Nevertheless, we remain confronted with the challenge of avoiding both types of error, Type I and Type II, in the context of endangered species protection. We do not want to increase socioeconomic costs more than necessary, but also do not want to allow activities that unduly threaten imperiled species. Hence, while neither the Scientific Method nor the Precautionary Principle Method is the law of the ESA, each may have something valuable to offer. A challenge for ESA methodology, therefore, is establishing a framework with the Professional Judgment Method at its core, but with the Scientific Method and Precautionary Principle Method in play.

In choosing a starting point for building such a framework, it is useful to keep in mind the goal of the ESA: "to halt and reverse the trend toward species extinction, whatever the cost." ${ }^{198}$ This purpose suggests a heightened aversion to Type II error, but it does not require that we tolerate Type I error unnecessarily. The Precautionary Principle Method has been held out as the means of reducing the ESA risk asymmetry that makes Type II error more likely as a structural matter, ${ }^{199}$ but its advocates offer no structure for avoiding runaway precaution driven by, and disguising, bias, ambition, or

\footnotetext{
196 Id. at 851.

197 Id. at 852.

198 Tenn. Valley Auth. v. Hill, 437 U.S. 153, 184 (1978).

199 See SCIENCE AND THE ESA, supra note 12 , at 169.
} 
arrogance. As the Klamath Committee explained in light of what appeared to be a precautionary move by FMS and NMFS in curtailing irrigation from the Klamath Project, the Committee

\begin{abstract}
found its greatest differences with the resource agencies in... instances in which the agencies have used professional judgment that is contradicted by scientifically valid, relevant evidence. In carrying out its task to categorize the scientific support for specific proposals, the committee would characterize any proposal justified by such means as having negligible scientific support. This does not preclude the resource agency from using such an approach, but the justification for it would involve extreme sensitivity to risk, and in this way might be judged not reasonable. ${ }^{200}$
\end{abstract}

Left unrestrained, in other words, the Precautionary Principle Method would allow agencies to slide precariously into blind ambition and sheer arrogance, with little chance for meaningful public oversight or judicial review. One indicia of when policy-based precaution has given way to illegitimate motives is when the decision is flatly not consistent with the available scientific information, or with only a small portion of the information. Hence, rather than use the precautionary principle to guide scientific evaluation of ESA decisions, the reverse should apply-scientific evaluation should be used by policy makers to decide whether the agency adequately considered the best available scientific evidence and properly employed policy-based decision-making tools such as the precautionary principle to reach its decision.

In the manner I propose below, therefore, the conflict between the Scientific Method and Precautionary Principle Method can be turned to the benefit of keeping the ESA on an even keel. To summarize, my proposal is guided by three central themes:

1) The Professional Judgment Method should be the workhorse of most agency decisions under the ESA. The "best available scientific evidence" standard clarifies what sound professional judgment entails in those situations, which will define most cases under the ESA, when data do not permit decisions based on methods as demanding as the scientific method.

2) The Precautionary Principle Method should be within the agency's discretion to implement when deciding cases for which a) the evidence is inconclusive or even points against taking protective measures, but for which b) there is sufficient cause to believe that a decision not to take protective measures could be wrong and, if so, the consequences thereof could place the species on an irreversible path toward extinction. These cases should be infrequent, but where they arise the agency should have the discretion to act proactively even against the tide of evidence. The ESA is, after all, about preventing extinction.

3) Nevertheless, the Precautionary Principle Method requires a structured decision-making context to guard against cases of arrogance or

200 KLAMATH COMMITTEE FinAL REPORT, supra note 119 , at 37 , 
ambition disguised as the precautionary principle. The Scientific Method supplies the tools to provide this necessary structure. Any instance in which the agency implements the Precautionary Principle should be the subject of robust, independent scientific peer review to determine how out of line the decision is scientifically with the best available scientific evidence.

Structurally, the process would look as follows:

1) FWS or NMFS can elect to use the Precautionary Principle Method in any ESA decision node event if it deems the best scientific data available, while not strongly supporting a decision to extend protection to a species, indicates with reasonable confidence that the risk of Type II error is more than insubstantial and that the consequences would be severe.

2) That finding would suspend any applicable statutory deadline for decision and trigger a peer review, at agency expense, commensurate with the rigor applied in the Klamath Committee setting. NRC could be used to facilitate the peer review and ensure its independence ${ }^{201}$ and intensity. ${ }^{202}$ Unlike the Klamath Committee, however, the peer review committee would not be asked to conduct a scientific peer review of the agency's entire record and decision. Rather, the peer review committee would be asked to evaluate whether the scientific basis for the agency's conclusions regarding the risk and consequences of Type II error is substantial - that is, not conclusive, just substantial. $^{203}$

3) Following the completion of the peer review, the agency could revise its decision or choose not to at its peril (see 4 below). In any event, in its final decision the agency would be required to explain why it has or has not revised its decision consistent with the peer review results. ${ }^{204}$

201 See supra note 122 (providing NRC's definition of independence).

202 The NRC's Klamath Committee consisted of 12 professionals and was assisted by several NRC staff members. It made three field trips to the Klamath Basin and held one additional meeting of the entire committee. NRC committee members receive no compensation, but are fully reimbursed for their travel expenses. The Klamath Committee's budget was over $\$ 650,000$. Clearly, not all peer review events contemplated under my proposal would necessitate this scale of effort, but some would. NRC and the agency requesting the peer review under my proposal would negotiate the scale of effort and budget consistent with NRC's current practices.

203 Here, of course, lies the rub-I do not articulate a more precise standard for knowing when there is a sound scientific basis for concluding that the risk and consequences of Type II error meet the prescribed thresholds. There is an ongoing effort among many ecologists, economists, and policy thinkers to describe this threshold with more precision. See S.W. Pacala et al., False Alarm over Environmental False Alarms, 301 SCIENCE 1187 (Aug. 29, 2003) (proposing a marginal cost-benefit analysis basis for measuring "sensitivity" to Type II error); Gordon K. Durmil, How Much Information Do We Need Before Exercising Precaution, in Implementing the Precautionary Principle, supra note 21, at 266; see generally Stephen Charest, Bayesian Approaches to the Precautionary Principle, 12 DukE EnVTL. L. \& POL'Y F. 265 (proposing a method based on Bayesian rather than frequentist statistical analysis); see also SCIENCE AND THE ESA, supra note 12, at 157-74 (emphasizing the need to use structured approaches in ESA decision making and exploring frameworks used and tradeoffs made between competing objectives). This is the kind of issue that would be appropriate for an entity like NRC to examine as a general matter before the procedures I proposed are implemented in discrete decision settings.

204 The agencies' existing peer review policy does not require this, and the agencies often are not forthcoming about why they agree or disagree with their (hand-picked) peer reviewers. See, 
4) In any subsequent action for judicial review of the agency's final decision, the court would be required to give the findings of the peer review "great deference"-basically, they would be accepted as stipulated fact and thus would trump any data not consistent with those findings. This would provide the agency a safe harbor when it follows the results of the peer review, and would deter litigation seeking to move the agency away from those results. On the other hand, this would place the agency at great risk if it does not follow the results of the peer review by making it easier for anyone challenging the final decision to establish that the agency has acted arbitrarily and capriciously.

Moreover, although the judicial review provisions outlined above may make it attractive to FWS and NMFS to follow this procedure when they wish to employ precautionary decision measures, the risk of an adverse peer review may prove sufficiently undesirable to the agencies that they may be willing to risk adopting precautionary measures under their normal Professional Judgment Method and hope not to be reversed under the conventional judicial review rules. To guard against systematic abuses in that regard, the following additional procedures would apply:

1) Any other federal agency, state, local, tribal, or private entity can petition for review of an FWS or NMFS decision alleged to have exercised undue precaution-i.e., lacking a substantial scientific basis for concluding that the risk and consequences of Type II error are substantial.

2) A standing panel of NRC scientists would examine the petition and the administrative record to decide whether it has a substantial basis. A negative panel finding would leave the petitioner to its normal recourse; however, in order to deter frivolous petitions, the negative finding would become part of the administrative record for purposes of any judicial review action and would be afforded great deference therein, as described above. A positive panel finding would lead either to voluntary remand of the decision by FWS or NMFS for further development, or to the decision by the agency explicitly to elect to use the Precautionary Principle Method and thereby to trigger the peer review procedure described above.

This kind of two-staged review process is not unprecedented in the ESA. FWS and NMFS may, for example, list species on an emergency basis using a lower (and thus more precautionary) standard of proof, but then must complete the listing process under the normal standards of proof if the species is to remain listed beyond a prescribed time period. ${ }^{205}$ And where FWS or NMFS find "that there is substantial disagreement regarding the sufficiency or accuracy of the available data" concerning a listing decision,

e.g., Endangered and Threatened Wildlife and Plants; Withdrawal of the Proposed rule to List the Mountain Plover as Threatened, 68 Fed. Reg. 53,083 (Sept. 9, 2003) (to be codified at 50 C.F.R. pt. 17) (After confirming the merits of a proposed rule to list the mountain plover that was supported in two rounds of peer review, FWS later withdrew the rule based ostensibly on new information, but without additional peer review.).

205 See 16 U.S.C. $\S 1533(b)(7)$ (2000) (allowing emergency listing based on finding of an "emergency posing a significant risk to the well-being of any species"); City of Las Vegas v. Lujan, 891 F.2d 927, 932 (D.C. Cir. 1989) (noting that emergency listings are subject to a "somewhat less rigorous process of investigation and explanation"). 
they may extend the deadline for decision for up to six months "for purposes of soliciting additional data." ${ }^{206}$ Moreover, legal processes routinely allow precautionary measures, such as the preliminary injunction, to preserve the status quo on preliminary showings of proof pending more rigorous evidentiary development and review. ${ }^{207}$ In all such cases, however, there is a structured basis for taking the precautionary step, for reviewing its merits under closer scrutiny, and for reconsidering it. By contrast, advocates of using the Precautionary Principle Method in ESA decision making simply toss it out there as a holistic talisman that somehow is supposed to work its good luck in the absence of any prescribed process or standards. I am for precaution under the ESA, but not that way. I am for it only if I am sure it will not dissolve agency decision making into blind ambition and arrogance.

\section{CONCLUSION}

Clearly, "sound science" legislation does not adopt the framework I propose, opting instead for emphasizing features of the Scientific Method in many more cases than does my proposal, and leaving the Precautionary Principle Method out of the picture entirely. One motivating factor for that approach, perhaps, is that in the real world FWS and NMFS could not be trusted to be honest about their use of the precautionary principle. There is, after all, evidence that the agencies attempt to make cases decided on the basis of precaution look like they were decided under conventional Professional Judgment Method procedures, trying to make the evidence on behalf of precaution look better than it truly is. ${ }^{208}$ On the other hand, if the framework I propose were formally adopted in the ESA, the agencies may very well embrace it as providing clear avenues of precautionary decision making with methodological safeguards that protect, rather than harm, the agency's decision-making integrity.

The Klamath River Basin experience illustrates just how important the battle over ESA methodology will be, and how important it will be to devise some framework that improves on the present system, whether it is mine or another. It is no exaggeration to say that the landscape, culture, economy, and ecology of the Klamath hinge on how the ESA is implemented. Peoples' ways of life are at stake. Three species' continued existences on the planet are at stake. The NRC peer review was intended to add clarity to the situation, but that could be lost in the circus-like battle of competing methodological visions. We owe it to the people and species of the Klamath, and of the next Klamath and the ones thereafter around the nation's landscape, to bring order to ESA methodology.

20616 U.S.C. $\$ 1533($ b)(6)(B)(i) (2000).

207 I thank my faculty colleague Barbara Banoff for this analogy, and point as an example in the species protection context to Greater Yellowstone Coalition v. Flowers, 321 F.3d 1250 (10th Cir. 2003) (reversing lower court's denial of preliminary injunction against project in protected eagle habitat).

208 See the cases discussed supra notes 187-97 and accompanying text. 